\title{
Article \\ Effect of Al and Mg Doping on Reducing Gases Detection of ZnO Nanoparticles
}

\author{
Soumaya Jaballah ${ }^{1}$, Yazeed Alaskar ${ }^{2}$, Ibrahim AlShunaifi ${ }^{3}$, Imed Ghiloufi ${ }^{1,4}$, Giovanni Neri ${ }^{5}$ (D), \\ Chaker Bouzidi ${ }^{6}$, Hassen Dahman ${ }^{1}$ and Lassaad El Mir ${ }^{1,4, *}$
}

1 Laboratory of Physics of Materials and Nanomaterials Applied at Environment (LaPhyMNE), Faculty of Sciences in Gabes, Gabes University, Gabes 6072, Tunisia; soumayajaballah92@gmail.com (S.J.); ghiloufimed@yahoo.fr (I.G.); has.dahman@gmail.com (H.D.)

2 King Abdulaziz City for Science and Technology (KACST), Material Science Research Institute, Riyadh 11442, Saudi Arabia; yalaskar@kacst.edu.sa

3 King Abdulaziz City for Science and Technology (KACST), National Center for Combustion \& Plasma Technology, Riyadh 11442, Saudi Arabia; alshunaifi@kacst.edu.sa

4 Department of Physics, College of Sciences, Imam Mohammad Ibn Saud Islamic University (IMSIU), Riyadh 11623, Saudi Arabia

5 Department of Engineering, University of Messina, 98166 Messina, Italy; gneri@unime.it

6 National Center for Research in Materials Sciences, Technopole Borj Cédria, Laboratory of Physico-Chemistry of Mineral Materials and Their Applications, BP 73, Soliman 8027, Tunisia; Chaker.bouzidi1978@gmail.com

* Correspondence: Lassaad.ElMir@fsg.rnu.tn

\section{check for} updates

Citation: Jaballah, S.; Alaskar, Y.; AlShunaifi, I.; Ghiloufi, I.; Neri, G.; Bouzidi, C.; Dahman, H.; El Mir, L. Effect of $\mathrm{Al}$ and $\mathrm{Mg}$ Doping on Reducing Gases Detection of $\mathrm{ZnO}$ Nanoparticles. Chemosensors 2021, 9 , 300. https://doi.org/10.3390/ chemosensors 9110300

Academic Editors: Bilge SaruhanBrings, Roussin Lontio Fomekong and Svitlana Nahirniak

Received: 2 September 2021

Accepted: 19 October 2021

Published: 24 October 2021

Publisher's Note: MDPI stays neutral with regard to jurisdictional claims in published maps and institutional affiliations.

Copyright: (c) 2021 by the authors. Licensee MDPI, Basel, Switzerland. This article is an open access article distributed under the terms and conditions of the Creative Commons Attribution (CC BY) license (https:/ / creativecommons.org/licenses/by/ $4.0 /)$.

\begin{abstract}
In this work, the main objective is to enhance the gas sensing capability through investigating the effect of $\mathrm{Al}$ and $\mathrm{Mg}$ doping on $\mathrm{ZnO}$ based sensors. $\mathrm{ZnO}, \mathrm{Mg}_{1 \%}$ doped $\mathrm{ZnO}, \mathrm{Al}_{5 \%}$ doped $\mathrm{ZnO}$ and $\left(\mathrm{Al}_{5} \%, \mathrm{Mg}_{1 \%}\right)$ co-doped $\mathrm{ZnO}$ nanoparticles (NPs) were synthesized by a modified sol-gel method. The structural characterization showed the hexagonal crystalline structure of the prepared samples. Morphological characterizations confirmed the nanometric sizes of the NPs (27-57 nm) and elemental composition investigation proved the existence of $\mathrm{Al}$ and $\mathrm{Mg}$ with low concentrations. The optical characterization showed the high absorbance of the synthesized samples in the UV range. The gas sensing performances of the synthesized samples, prepared in the form of thick films, were investigated. Sensing tests demonstrated the high influence of the $\mathrm{Al}$ and $\mathrm{Mg}$ on the sensing performances towards $\mathrm{H}_{2}$ and $\mathrm{CO}$ gas, respectively. The 5A1MZO-based sensor exhibits high sensitivity and low detection limits to $\mathrm{H}_{2}(<2 \mathrm{ppm})$ and $\mathrm{CO}(<1 \mathrm{ppm})$. It showed a response around 70 (at $250{ }^{\circ} \mathrm{C}$ ) towards $2000 \mathrm{ppm} \mathrm{H}_{2}$ and $2\left(\right.$ at $250{ }^{\circ} \mathrm{C}$ ) towards $\mathrm{CO}$.
\end{abstract}

Keywords: $\left(\mathrm{Al}_{5 \%}, \mathrm{Mg}_{1 \%}\right)$ co-doped $\mathrm{ZnO}$; nanoparticles; sol-gel; gas sensor; hydrogen; carbon monoxide

\section{Introduction}

$\mathrm{ZnO}$ is an important semiconductor material that exhibits a wide range of properties for vast area of applications. The unique characteristics like wide bandgap $(3.37 \mathrm{eV})$, high excitonic binding energy $(60 \mathrm{meV})$ at room temperature, high-electron mobility, high chemical and thermal stability, strong cohesive energy $(1.89 \mathrm{eV})$ and good biocompatibility make $\mathrm{ZnO}$ a favorable material for gas sensors [1-3]. Furthermore, the non-toxicity, low-cost, simplicity in fabrication, suitability for bulk production and robustness in practical applications, make $\mathrm{ZnO}$ very interesting to be used as a sensing material compared to other semiconducting metal oxides $[4,5]$. Several approaches were adopted to synthesize pure and doped $\mathrm{ZnO}$ nanoparticles, such as sol-gel [6], combustion, co-precipitation, hydrothermal [7], thermal stock [8], laser ablation in liquid [9] and the sonochemical method [10]. Among them, the sol-gel method is relatively simple, needs low-cost equipment and a low reaction temperature. On the other hand, it allows producing materials of high purity and crystallinity and with different shapes [11]. The preparation of pure, doped and co-doped $\mathrm{ZnO}$ NPs by sol-gel method for gas sensing is our main investigation. 
Various materials such as graphene, polymers, small organic materials and semiconductor oxides are used for the sensitive detection of certain reducing gases [12,13]. Zinc oxide is one of the semiconductor oxides that attracted great attention thanks to its low coast, non-toxicity, flexibility in production and sensitivity to different gases [14]. ZnObased gas sensors have exposed excessive abilities to detect harmful and flammable gases like $\mathrm{CO}[15,16], \mathrm{CO}_{2}[17], \mathrm{NO}_{2}[18,19], \mathrm{CH}_{4}[20,21], \mathrm{NH}_{3}$ [22,23] and $\mathrm{H}_{2}$ [24,25]. However, using pure $\mathrm{ZnO}$ as a sensing layer has some limitations, such as the high working temperature and detection limit, low selectivity, and the long response/recovery times. Doping $\mathrm{ZnO}$ with suitable elements is one of the methods used to improve the gas sensing properties. Group III elements, such as $\mathrm{In}, \mathrm{Al}$ and $\mathrm{Ga}$, and group-II elements, such as $\mathrm{Mg}$ and $\mathrm{Ca}$, are widely used as n-type dopants in $\mathrm{ZnO}$ material $[26,27]$. They incorporate into $\mathrm{ZnO}$ material by replacing the host atoms $\mathrm{Zn}$. This induces the release of free electrons and also contributes to high conductivity in $\mathrm{ZnO}$ material [28].

In this context, we have reported in our previous work [26] a considerable improvement in formaldehyde sensing of Ca-doped $\mathrm{ZnO}$ NPs-based sensor due to the basic centers provided by calcium which induces high gas adsorption. Moreover, Ga doped ZnO NPs were prepared by Dhahri et al. [5]. The substitution of the $\mathrm{Zn}^{2+}$ by the $\mathrm{Ga}^{3+}$ cation induces more oxygen species formation that are able to be chemisorbed. The Ga doped $\mathrm{ZnO}$-based sensor showed a capacity to detect low CO concentrations at relatively lower operating temperature $\left(200^{\circ} \mathrm{C}\right)$. Additionally, it showed higher sensitivity and faster response/recovery times compared to pure $\mathrm{ZnO}$ sensor. Due to the sensing results given by $\mathrm{Ca}$ (group II) and $\mathrm{Ga}$ (group III) doping, we have chosen the $\mathrm{Mg}$ and $\mathrm{Al}$ doping agents.

In the present paper, we are interested in aluminum and magnesium elements. We synthesized and characterized $\mathrm{ZnO}, \mathrm{Mg}$-doped $\mathrm{ZnO}, \mathrm{Al}$-doped $\mathrm{ZnO}$ and $(\mathrm{Al}, \mathrm{Mg}$ ) codoped $\mathrm{ZnO}$ NPs and studied the effect of $\mathrm{Al}$ and $\mathrm{Mg}$ on gas sensing properties. $\mathrm{Al}$ and $\mathrm{Mg}$ doping have improved the response toward the reducing gases $\mathrm{H}_{2}$ and $\mathrm{CO}$, respectively, by inducing electronic effects which alter the reactivity of the detection layer's surface. In the following, we present the preparation process of the NPs, the used characterization techniques and a description of the experimental setup and measurements of the gas sensor. Then, we present and interpret the obtained results.

\section{Experimental Details}

\subsection{Preparation Process}

The samples (pure, doped and co-doped ZnO NPs) were prepared by a modified sol-gel route. $\mathrm{Mg}$ doped $\mathrm{ZnO} \mathrm{NPs}$ were prepared by dissolving $16 \mathrm{~g}$ of zinc acetate dehydrate $\left[\mathrm{Zn}\left(\mathrm{CH}_{3} \mathrm{COO}\right)_{2} \times 2 \mathrm{H}_{2} \mathrm{O}, 99 \%\right]$ in $112 \mathrm{~mL}$ of methanol under magnetic stirring at an ambient temperature. Then an adequate quantity of magnesium chloride hexahydrate $\left(\mathrm{MgCl}_{2} \times 6 \mathrm{H}_{2} \mathrm{O}\right)$ corresponding to a ratio $[\mathrm{Mg}] /[\mathrm{Zn}]$ of $0.01(1 \mathrm{at} . \%)$ was added under magnetic stirring until total dissolution. The above solution was placed in an autoclave with about $220 \mathrm{~mL}$ of ethanol before being dried in the supercritical conditions of ethyl alcohol $\left(\mathrm{Tc}=243{ }^{\circ} \mathrm{C} ; \mathrm{Pc}=63.6\right.$ bars $)$ according to $\mathrm{El}$ Mir et al.'s protocol $[29,30]$. The reaction of the formation of $\mathrm{ZnO}$ is given in (Equation (1)) for temperature range from 180 to $300^{\circ} \mathrm{C}$.

$$
\mathrm{Zn}\left(\mathrm{CH}_{3} \mathrm{CO}_{2}\right)_{2}+\mathrm{H}_{2} \mathrm{O} \rightarrow \mathrm{ZnO}+2 \mathrm{CH}_{3} \mathrm{COOH}
$$

The same protocol was used to prepare Al-doped $\mathrm{ZnO}$ NPs. The $\mathrm{Al}$ precursor was the aluminum isoproxide $\left(\mathrm{C}_{9} \mathrm{H}_{21} \mathrm{AlO}_{3}\right)$ and the $[\mathrm{Al}] /[\mathrm{Zn}]$ atomic ratio was $0.05(5$ at.\%). The $\mathrm{Al}-\mathrm{Mg}$ co-doped sample was also prepared by the same adopted protocol. The magnesium and aluminum precursors were introduced simultaneously after dissolving zinc precursor ( 1 at.\% $\mathrm{Mg}$ and 5 at.\% $\mathrm{Al}$ ). At the end, the gained nanopowders were annealed, in a muffle furnace, at $400{ }^{\circ} \mathrm{C}$ in air for $2 \mathrm{~h} . \mathrm{Mg}_{1 \%}$ doped $\mathrm{ZnO}, \mathrm{Al}_{5 \%}$ doped $\mathrm{ZnO}$ and $\left(\mathrm{Al}_{5 \%}, \mathrm{Mg}_{1 \%}\right)$ co-doped zinc oxide are named, respectively, as $1 \mathrm{MZO}, 5 \mathrm{AZO}, 5 \mathrm{~A} 1 \mathrm{MZO}$ in the present investigation. 


\subsection{Characterization Techniques}

Microstructural characterization was determined using X-ray diffraction (XRD, Philips PW1710) analysis with $\mathrm{Cu}-\mathrm{K}_{\alpha 1}$ radiations of wavelength $1.541874 \AA$. The surface morphology of the samples was analyzed using a transmission electron microscope (TEM; Tecnai G2-200 kV) and a field emission scanning electron microscopy (FESEM, type). Elemental composition was analyzed using energy dispersive X-ray (EDX) spectroscopy. The optical characterization was investigated with a UV-Vis-NIR spectrophotometer (Shimadzu UV-3101PC).

\subsection{Sensing Tests}

The prepared samples were used to design gas sensor devices. The sensing device consists of an alumina substrate with size dimensions of $6 \mathrm{~mm} \times 3 \mathrm{~mm}$, a pair of $\mathrm{Pt}$ interdigitated electrodes distant with 200 microns on the top side and a Pt heater on the back side. The prepared NPs were mixed with deionized water and deposited on sensing device via screen printed method. After that, the sensor devices were placed in a stainless-steel test chamber and exposed to a constant flow rate $\left(100 \mathrm{~cm}^{3} / \mathrm{min}\right)$ of synthetic dry air and then to the flux of target gas (100-10,000 ppm of $\mathrm{H}_{2}$ and 5-50 ppm of $\mathrm{CO})$. The concentrations of the inserted target gas within the test chamber were equipped with certified gas mixtures bottles and a mass-flow controller array. A multimeter data acquisition unit (Agilent $34970 \mathrm{~A}$ ) was interfaced with a computer to measure the electrical resistance of the detection layer. The sensors temperature was controlled using a dual channel power supply instrument (Agilent E3632 A). For reducing gases, the gas response is defined as $\mathrm{Ra} / \mathrm{Rg}$, where $\mathrm{Ra}$ is the baseline resistance and $\mathrm{Rg}$ is the electrical resistance of the sensor at different target gas concentrations. Photos of the sensing device and measurement system are presented in Figure 1.

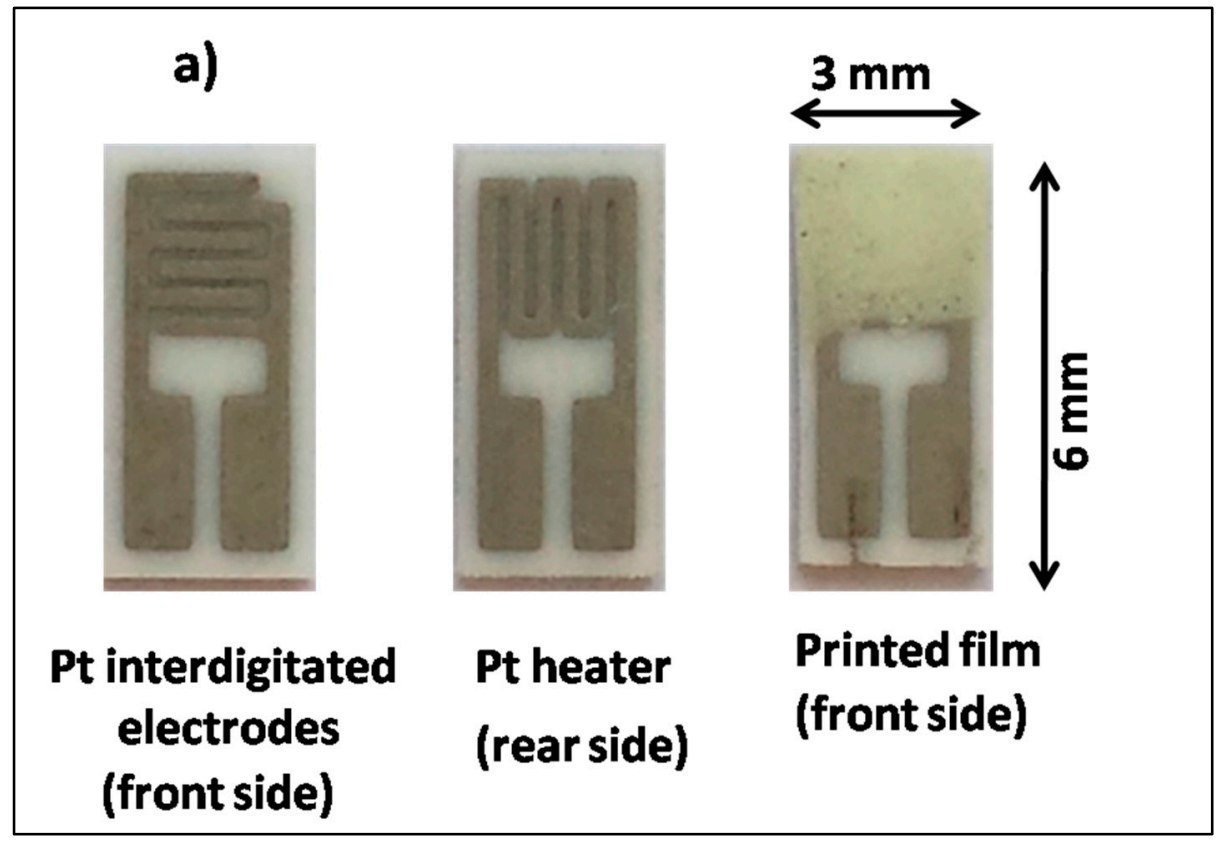

Figure 1. Cont. 


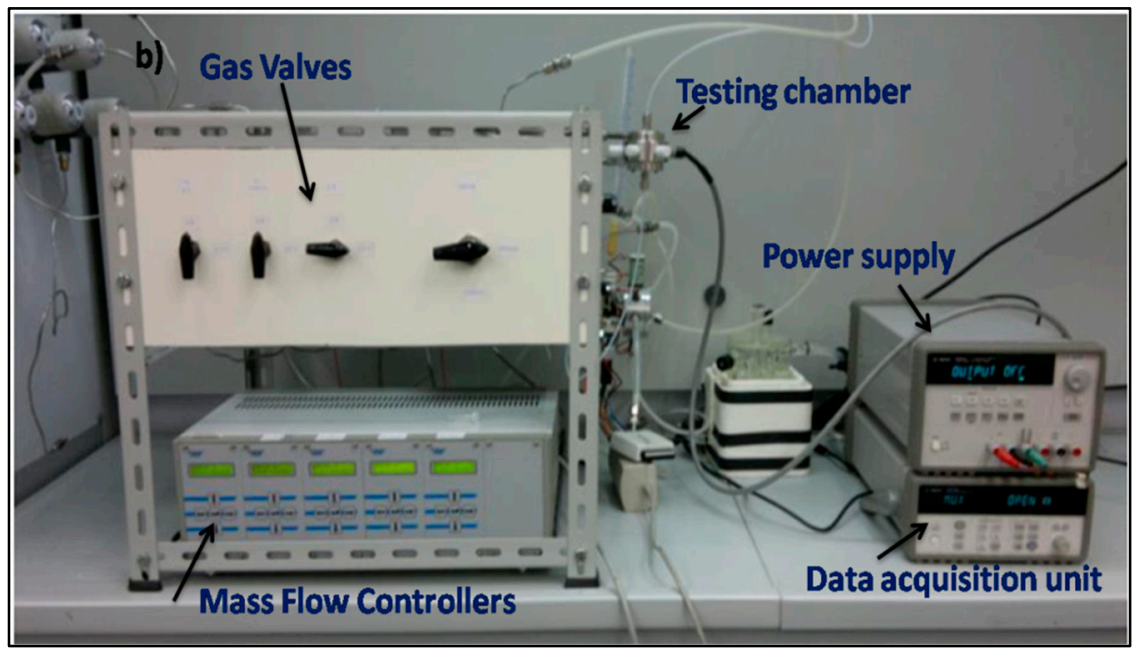

Figure 1. Photo of (a) the sensing device and (b) the measurement system.

\section{Results and Discussion}

\subsection{Characterization}

Figure 2 shows the XRD patterns of the $\mathrm{ZnO}, 1 \mathrm{MZO}, 5 \mathrm{AZO}$ and $5 \mathrm{~A} 1 \mathrm{MZO}$ samples. The high intensity and the sharpness of diffraction peaks indicate the well crystallized structure of the samples. The indexed diffraction peaks of the samples are associated to the hexagonal structure of $\mathrm{ZnO}$ (JCPDS Card No. 36-1451) [31]. The crystalline structure does not change expressively for the doped and co-doped samples and this may be due to the small amount of $\mathrm{Al}$ and $\mathrm{Mg}$ doping elements. No extra peaks from other phases are detected, indicating the high purity of the synthesized samples. Figure 3 illustrates a magnification of the major peak (101) of all samples. The peaks intensity becomes sharper and narrower for doped and co-doped samples, which confirms their high crystallinity. A slight shift of (101) peak, towards lower angles, is noticed for doped and co-doped samples compared to pure $\mathrm{ZnO}$. This shift suggests the incorporation of $\mathrm{Mg}$ and $\mathrm{Al}$ ions into the $\mathrm{ZnO}$ lattice, and it may be related to the difference in ionic radius of $\mathrm{Al}(0.53 \AA)$ and $\mathrm{Mg}$ $(0.72 \AA)$ with Zn $(0.74 \AA)$.

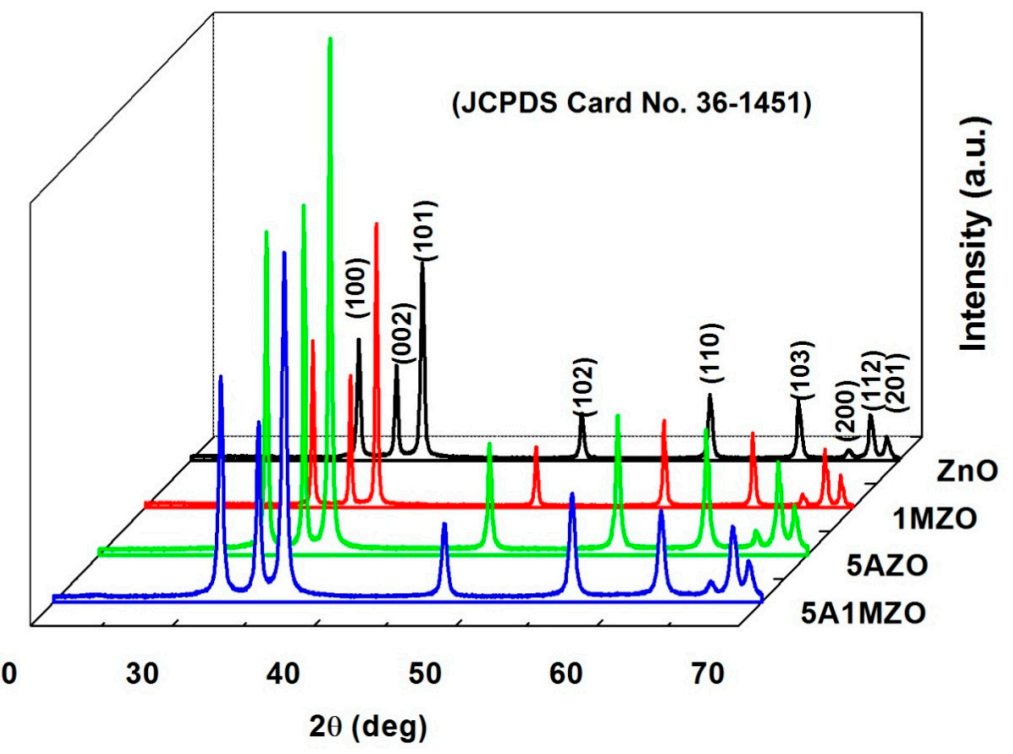

Figure 2. XRD diffractograms of $\mathrm{ZnO}, 1 \mathrm{MZO}, 5 \mathrm{AZO}$ and $5 \mathrm{~A} 1 \mathrm{MZO}$ samples. 


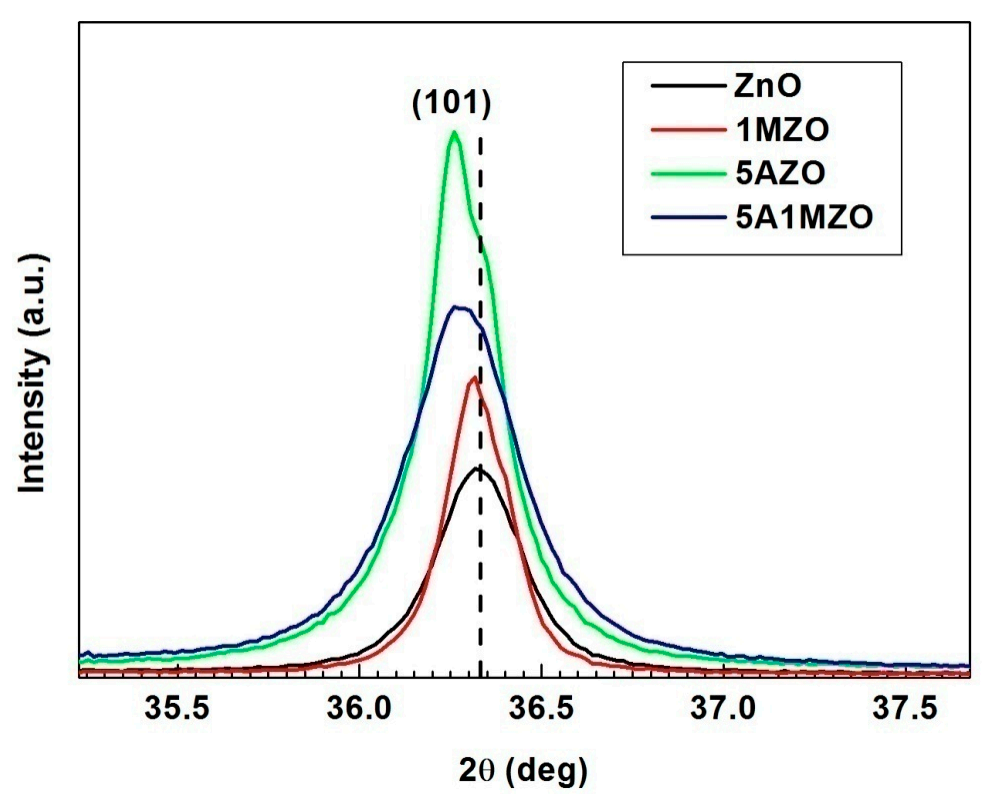

Figure 3. Shift of (101) peak of MZO, 5AZO and 5A1MZO from that of $\mathrm{ZnO}$ sample.

The crystallite size was estimated using the Scherrer's method [32] (Equation (2)) and the (101) plane was chosen for calculation.

$$
G=\frac{0.9 \lambda}{B \cos \theta}
$$

where $G$ is the average crystallite size, $\lambda$ is the X-ray wavelength (1.541874 $\AA$ ), $B$ is the full width at half-maximum peak (FWHM), and $\theta$ is the Bragg diffraction angle.

As shown in Table 1, the estimated crystallite sizes are approximately 36, 57, 35 and $27 \mathrm{~nm}$ for the $\mathrm{ZnO}, 1 \mathrm{MZO}, 5 \mathrm{AZO}$ and 5A1MZO, respectively. It seems that $\mathrm{Mg}$ doping induces grain growth. However, $\mathrm{Al}$ doping is responsible for the crystallite size decrease. Lattice parameters were calculated by Rietveld refinement using Fullprof program. Figure 4 presents the refined XRD pattern of the synthesized samples and Table 1 groups the estimated parameters values. They are in accordance with literature [33] and show small increase for doped and co-doped samples.

Table 1. Calculated results of crystallite size, lattice parameters and volume of the $\mathrm{ZnO}, 1 \mathrm{MZO}$, $5 \mathrm{AZO}$ and 5A1MZO samples.

\begin{tabular}{|c|c|c|c|}
\hline Samples & Crystallites Size (nm) & Lattice Parameters ( & Volume $\left(\AA^{3}\right)$ \\
\hline $\mathrm{ZnO}$ & 36 & $\begin{array}{l}a=3.246 \\
c=5.201\end{array}$ & 47.47 \\
\hline $1 \mathrm{MZO}$ & 57 & $\begin{array}{l}a=3.249 \\
c=5.206\end{array}$ & 47.61 \\
\hline $5 \mathrm{AZO}$ & 35 & $\begin{array}{l}a=3.250 \\
c=5.206\end{array}$ & 47.64 \\
\hline $5 \mathrm{~A} 1 \mathrm{MZO}$ & 27 & $\begin{array}{l}a=3.249 \\
c=5.203\end{array}$ & 47.58 \\
\hline
\end{tabular}

Figure 5 depicts low and high magnification SEM images of 1MZO and 5A1MZO nanoparticles. The samples show an agglomeration of sphere-shaped grains. It is observed that the sample surface is composed of agglomerated spherical particles, which are distributed all along the surface with uniform grain sizes. EDX analysis is a practical tool for detecting the chemical composition and the compounds stoichiometry. The EDX spectrum of 5A1MZO sample is shown in Figure 6. It shows distinct peaks related to zinc and oxygen 
atoms which presents the formation of ZnO NPs. Additionally, the higher peak at $1 \mathrm{keV}$ is a characteristic to $\mathrm{Zn}$ and it confirms the formation of ZnO NPs [34]. Furthermore, the EDX spectrum reveals the presence of $\mathrm{Zn}, \mathrm{O}, \mathrm{Al}$ and $\mathrm{Mg}$ elements with suitable proportions, which proves the successful doping of $\mathrm{Al}$ and $\mathrm{Mg}$ elements in the $\mathrm{ZnO}$ lattice as well as the high purity of the sample. This is in accordance with XRD results.
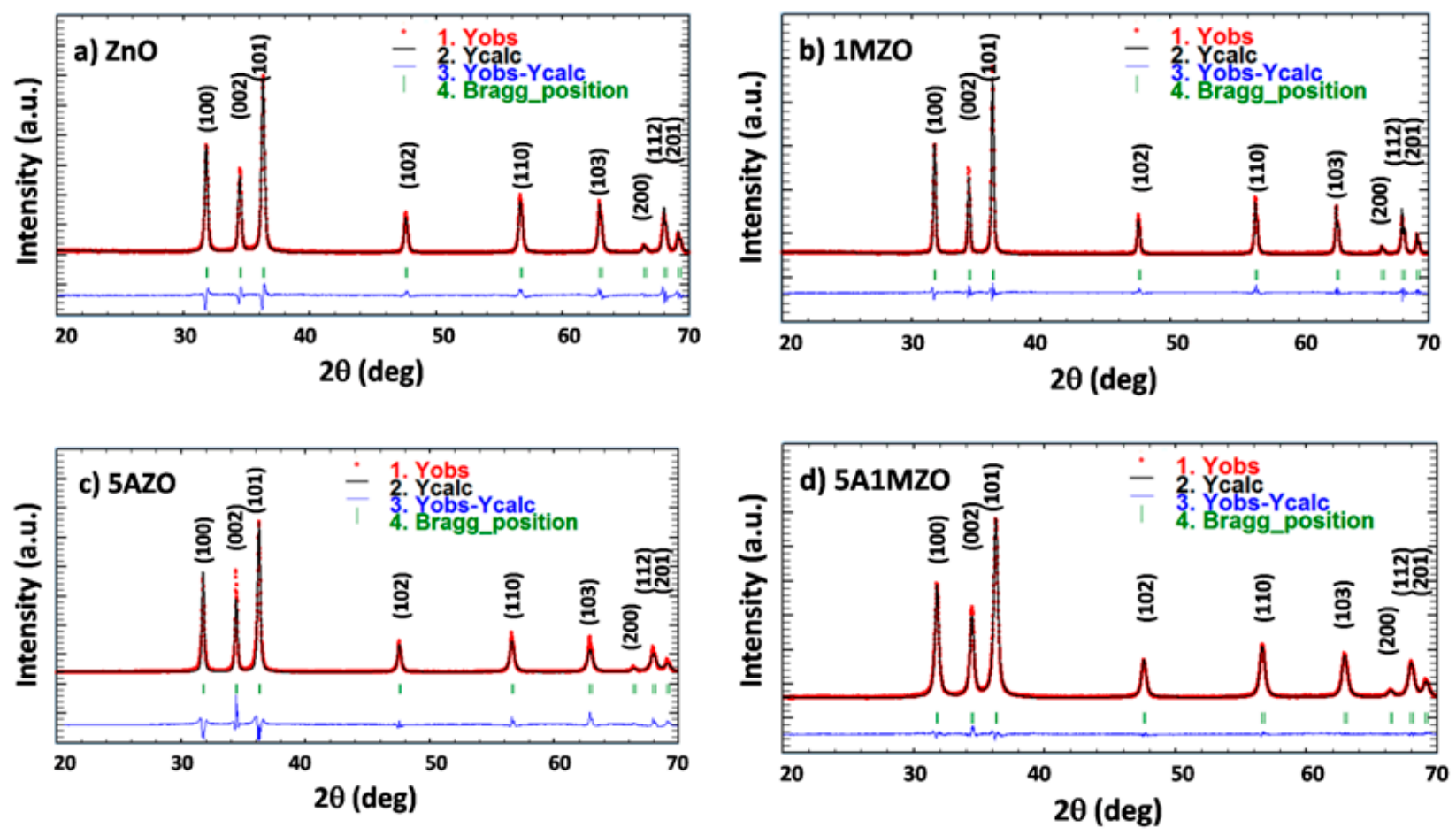

Figure 4. Fitted XRD patterns of (a) ZnO, (b) 1MZO, (c) 5AZO and (d) 5A1MZO nanoparticles.

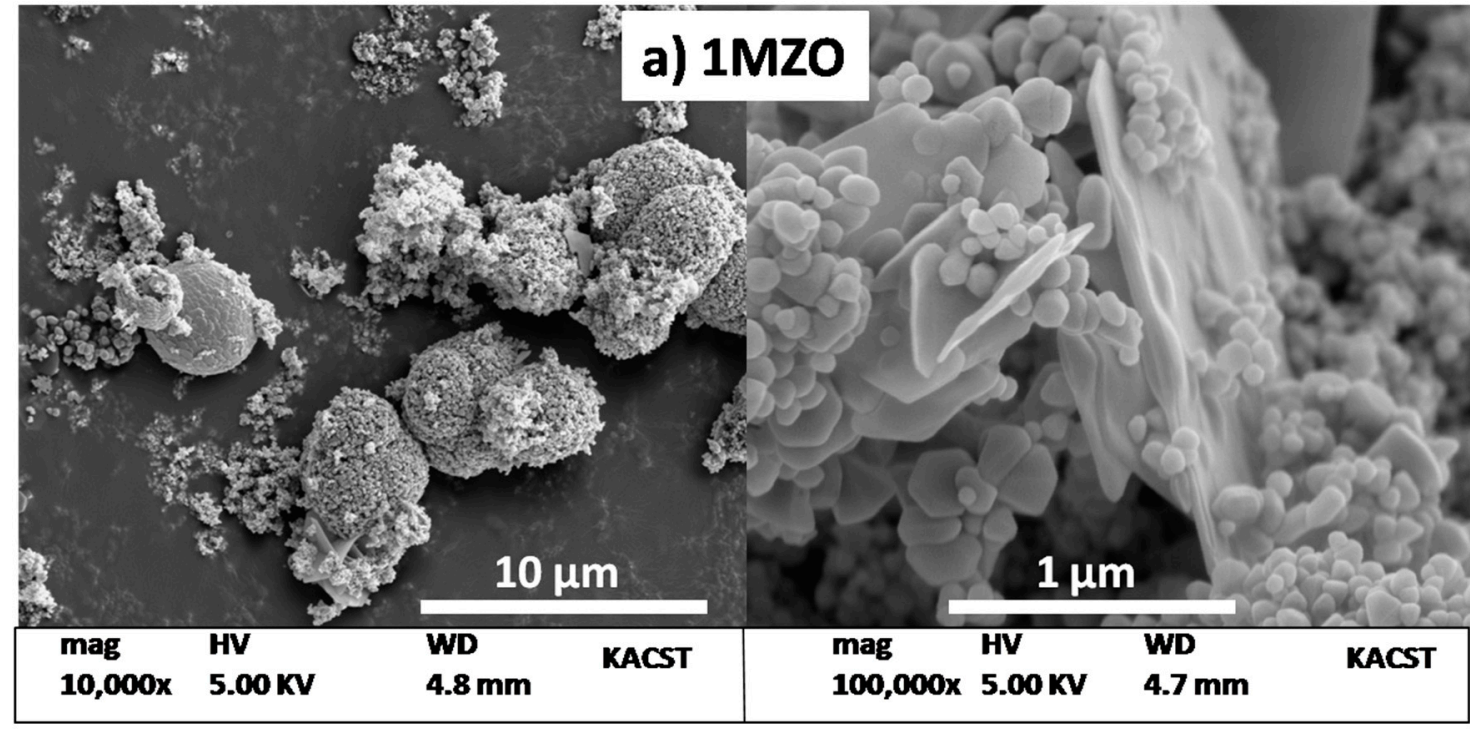

Figure 5. Cont. 


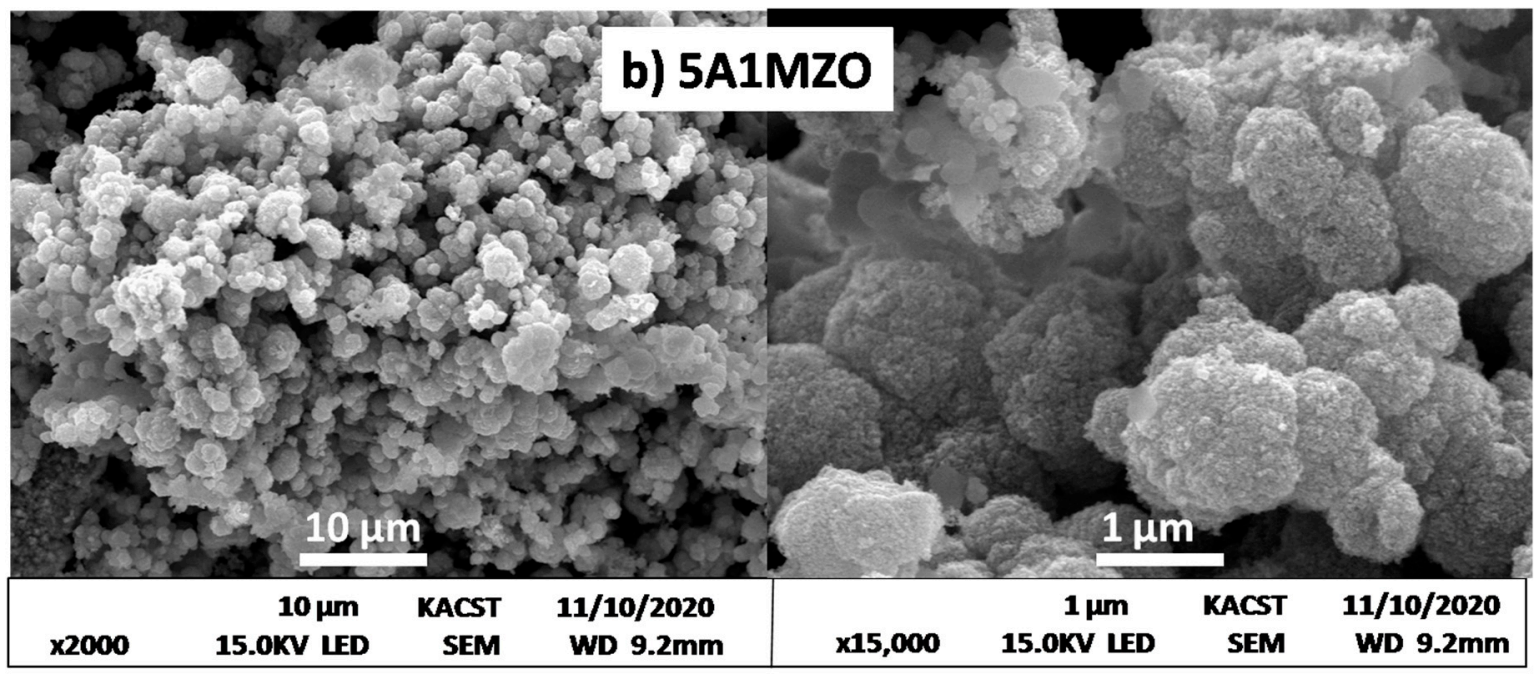

Figure 5. FESEM images of (a) $1 \mathrm{MZO}$ and (b) 5A1MZO at different magnifications.

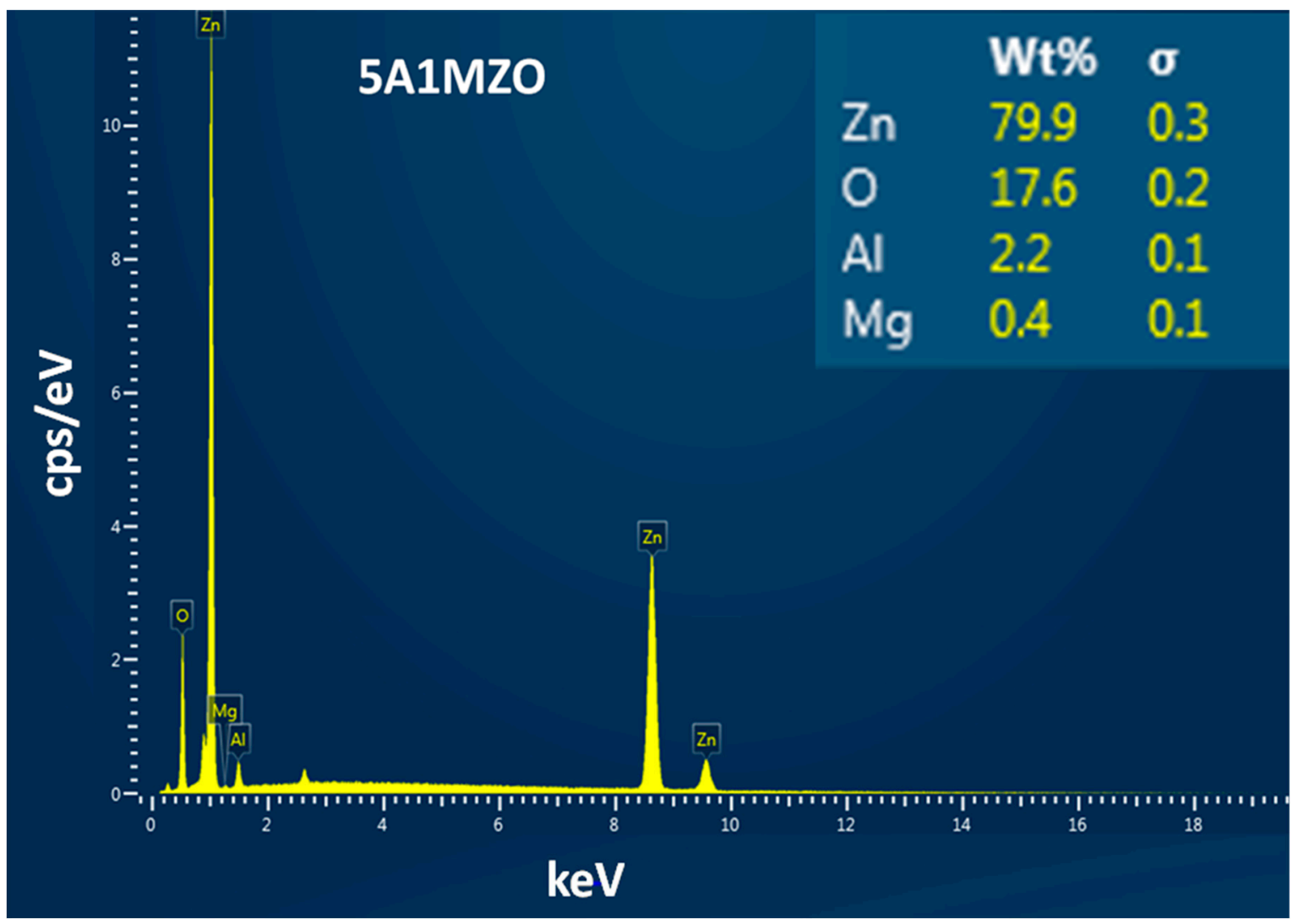

Figure 6. EDX spectrum of 5A1MZO sample.

Figure 7 reports a typical TEM image of 5A1MZO sample. The image shows prismatic shaped particles with nanometric size in the range of 15-26 nm. These crystallites size values agree well with those estimated by Scherrer's method $(27 \mathrm{~nm})$ in XRD part. The white spots indicate focused ultra-small nanoparticles on the surface which may assigned of the beginning of aggregation. These nanoparticles enface the specific surface area and then improve the sensing parameters. 


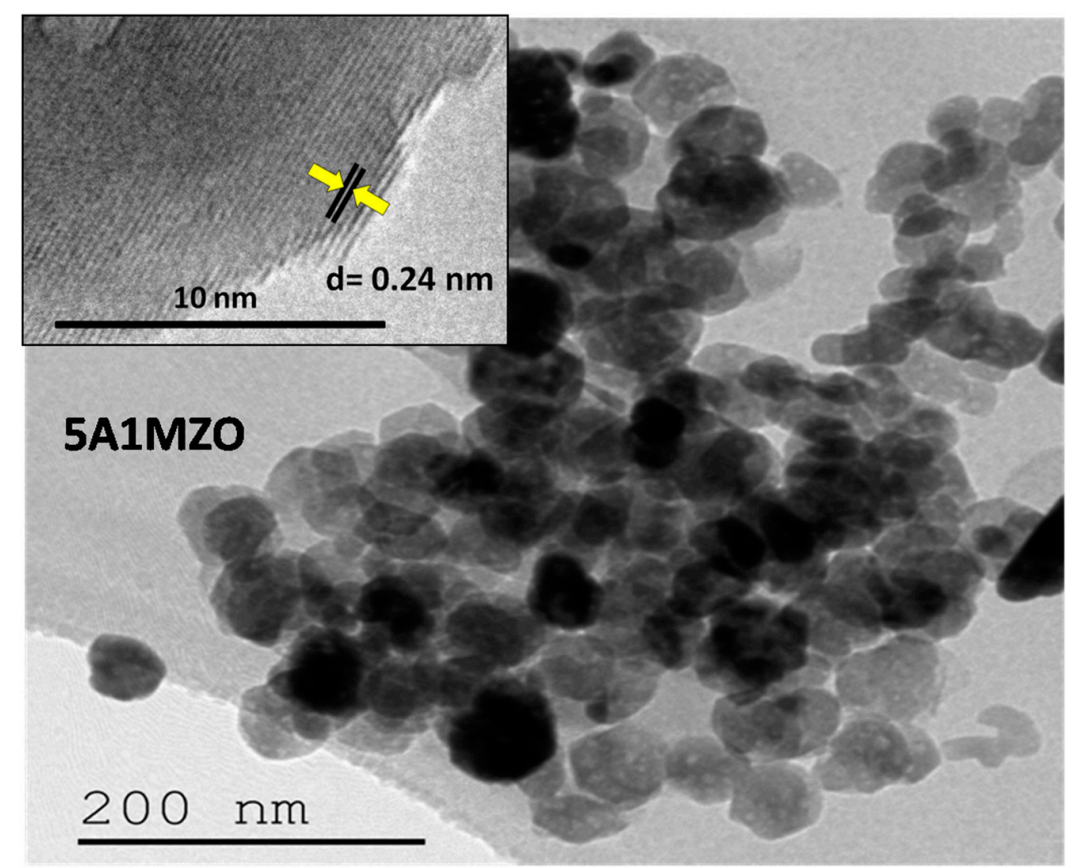

Figure 7. TEM image of 5A1MZO nanoparticles at $200 \mathrm{~nm}$. The inset presents the HRTEM image at $10 \mathrm{~nm}$.

The HRTEM image of 5A1MZO NPs shows parallel lattice fringes with spacing of $0.24 \mathrm{~nm}$, which corresponds to the (101) plane of crystalline $\mathrm{ZnO}$.

Figure 8 depicts the ultraviolet-visible absorption spectra of $\mathrm{ZnO}, 1 \mathrm{MZO}, 5 \mathrm{AZO}$ and $5 \mathrm{~A} 1 \mathrm{MZO}$ samples. For all samples, the highest absorption is noted in the UV region. These strong absorption peaks may be assigned to the electron transitions from the valence band (VB) to conduction band (CB) $(\mathrm{O} 2 \mathrm{p}-\mathrm{Zn} 3 \mathrm{~d})$ [35]. A low absorbance is noticed in the visible region while it slightly increases for $\mathrm{Mg}$-doped $\mathrm{ZnO}$ nanoparticles. This is may be ascribed to different factors, namely particle size, oxygen deficiency and lattice defects $[36,37]$. The band-gap energy $\left(E_{g}\right)$ was estimated from the Tauc's relation, described in equation (Equation (3)) [38] and the Tauc's plot is illustrated in Figure 9.

$$
(\alpha h v)^{2}=A\left(h v-E_{g}\right)
$$

where $\alpha$ is the absorption coefficient, $(h v)$ is the photon energy and $A$ is a constant.

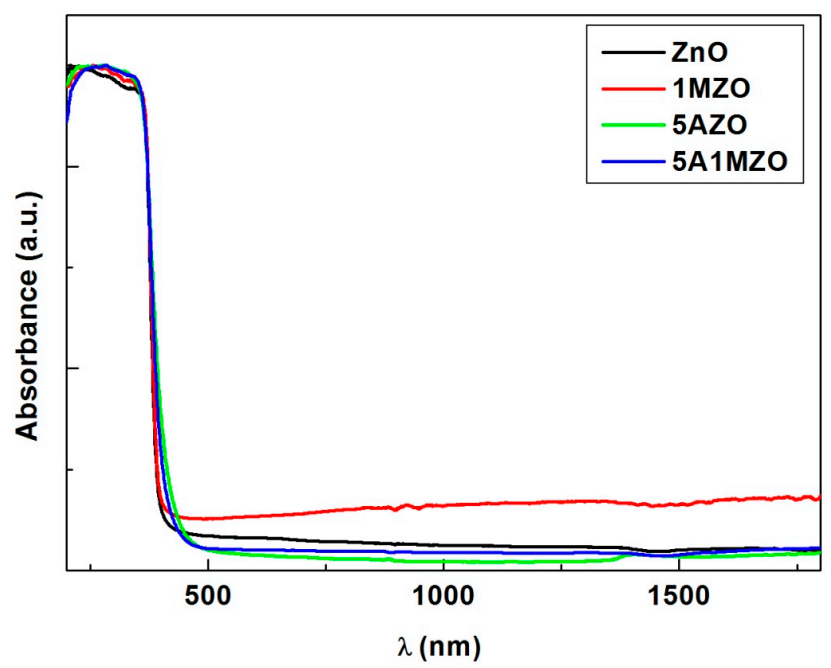

Figure 8. UV-Vis spectra of $\mathrm{ZnO}, 1 \mathrm{MZO}, 5 \mathrm{AZO}$ and 5A1MZO samples. 

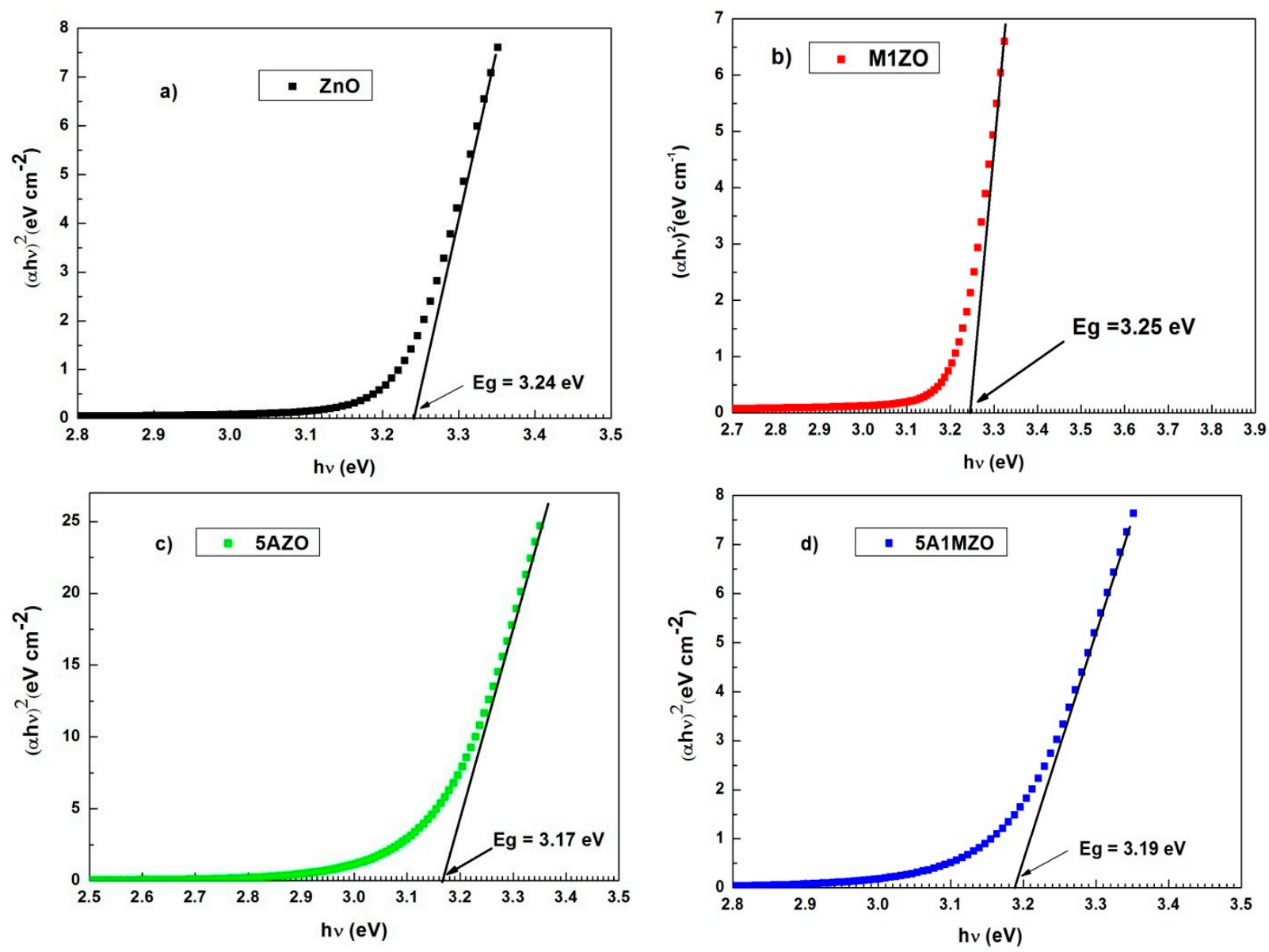

Figure 9. Plots of $(\alpha h v)^{2}$ versus photon energy (hv) for (a) ZnO, (b) 1MZO, (c) 5AZO and (d) 5A1MZO samples.

The estimated band gap was 3.24, 3.25, 3.17 and $3.19 \mathrm{eV}$ for $\mathrm{ZnO}, 1 \mathrm{MZO}, 5 \mathrm{AZO}$ and $5 \mathrm{~A} 1 \mathrm{MZO}$, respectively. The optical band gap energy slightly increases for $1 \mathrm{MZO}$. However, it decreases for $5 \mathrm{AZO}$ and $5 \mathrm{~A} 1 \mathrm{MZO}$ samples. It seems to be visible that $\mathrm{Mg}$ is responsible for the small enhancement in gap energy and aluminum is responsible for the gap energy shrinkage. The present increase in the gap energy of $1 \mathrm{MZO}$ sample was theoretically obtained by Rouchdi et al. [39]. It may be related to the variance in electronegativity and ionic radius of $\mathrm{Mg}$ and $\mathrm{Zn}$ atoms which introduce defects in the $\mathrm{ZnO}$ lattice. The decrease in the gap energy of $5 \mathrm{AZO}$ sample may be attributed to the strong $\mathrm{sp}-\mathrm{d}$ exchange interaction between the moving "sp" carriers, i.e., band electrons of $\mathrm{ZnO}$ and the localized d electrons of $\mathrm{Al}$ ions which substitute the $\mathrm{Zn}^{2+}$ ions [40]. Additionally, Caglar et al. [41] mentioned that $\mathrm{Al}$ doping induces narrowing band gap energy and it is possibly attributed to the carriers increase in the conduction band edge and to the new recombination centers formed with low emission energy.

\subsection{Gas Sensing Studies}

\subsubsection{Effect of $\mathrm{Al}$ on $\mathrm{Mg}$ Doped ZnO NPs-Based Sensor}

Hydrogen is an odorless and colorless gas with high flammability and large explosive limits (between 4 and $75 \%$ by volume) [42]. Exposure to high concentrations of hydrogen induces an oxygen-depleted environment which can provoke suffocation. Hydrogen may pose risks if not properly controlled and handled. Thus, hydrogen monitoring during its use, production transport and storage is very important for health and safety reasons.

The responses of $1 \mathrm{MZO}$ - and 5A1MZO-based sensors towards $\mathrm{H}_{2}$ as function of operating temperature $\left(200-300{ }^{\circ} \mathrm{C}\right)$ are illustrated in Figure 10. For both sensors, the response rises along with the operating temperature. This increase depends on the adsorption of gas molecules as well as the reactivity of the gas with the adsorbed oxygen species. At low 
temperatures, the sensors do not have sufficient energy to efficaciously absorb $\mathrm{H}_{2}$ onto its surface. Then, the response increases, and this may be assigned to the enhancement of the chemical activity on the sensor's surface. The doped-and co-doped-based sensors reach high response values at 250 and $300^{\circ} \mathrm{C}$ (more than 80 at $300^{\circ} \mathrm{C}$ ). It can be observed that $5 \mathrm{~A} 1 \mathrm{MZO}$ sensor shows higher sensitivity than $1 \mathrm{MZO}-$ based sensor. Undoubtedly, $\mathrm{Al}$ doping has effects on hydrogen sensing property of the $\mathrm{Mg}$ doped $\mathrm{ZnO}$ based sensor. Indeed, Al doping can change the AMZO acid-base characteristics and thereby its gas sensing aptitude. Additionally, it engenders smaller crystallites the size of the 5A1MZO sample, which provides larger effective surface area to react the gas, and induces higher crystallinity. All of these have a positive effect on sensitivity. These entire factors provided by $\mathrm{Al}$ doping may be responsible to the high sensitivity of $5 \mathrm{~A} 1 \mathrm{MZO}$ sensor [43,44]. On the other hand, Shi et al. [45] have recently reported the effect of doping with metals, such as $\mathrm{Mg}, \mathrm{Al}, \mathrm{Cd}, \mathrm{Co}$, In and $\mathrm{Cu}$, into $\mathrm{MOx}$ for $\mathrm{H}_{2}$ sensing. They outlined three main factors that make non-noble metals promising dopants for $\mathrm{MO}_{\mathrm{x}}$ materials. At first, the doping metal can induce a significant change in the grain size of $\mathrm{MO}_{\mathrm{x}}$ which increases the specific surface area of the material. The larger specific surface area induces more gas adsorption sites, and hence improves the sensing response capacity. Second, doping elements into the $\mathrm{MO}_{\mathrm{x}}$ lattice replace the position of the original metal particles and provoke lattice distortion. The lattice distortion can induce an increase in the surface defects of the materials which introduces a wide number of oxygen vacancies. This leads to an increase of the depletion layer on the material surface and a higher barrier. Hence, the sensor will be more sensitive to the targeted gas. At last, the doping metal ions can adjust the energy band structure by affecting the surface potential and the carrier concentration in the host material. This may cause quick charge transfer and the improvement of sensing properties.

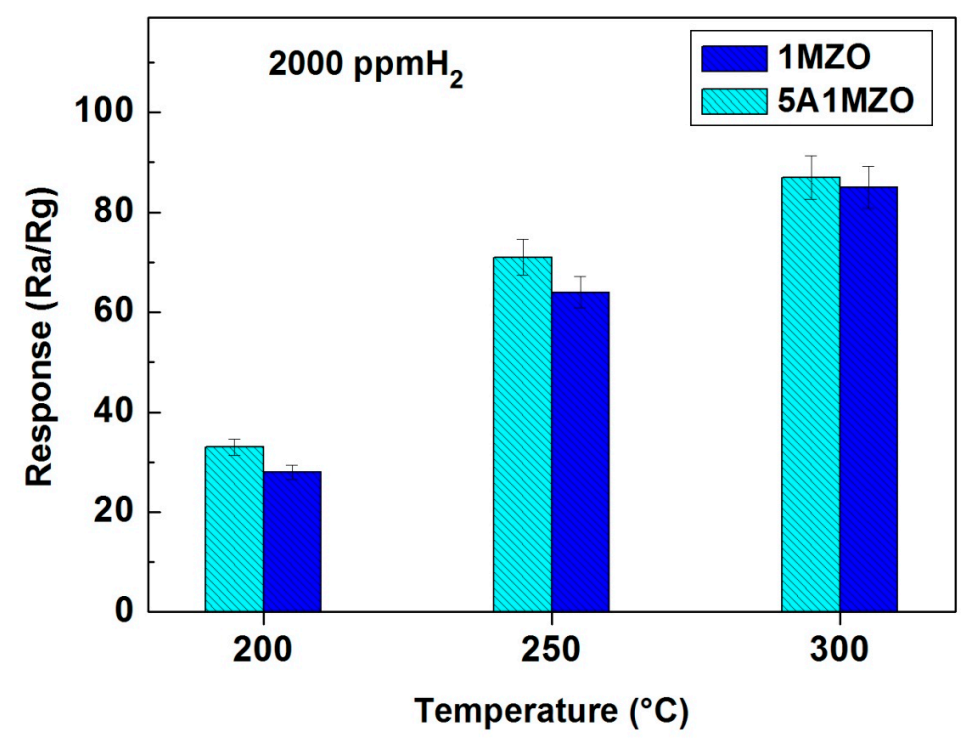

Figure 10. Responses of the 1MZO- and 5A1MZO-based sensors to 2000 ppm hydrogen versus operating temperatures.

Both sensors exhibit comparable response times (around $3 \mathrm{~s}$ at $250^{\circ} \mathrm{C}$ ). However, the recovery time was shorter for the $5 \mathrm{~A} 1 \mathrm{MZO}$ sensor $\left(70 \mathrm{~s}\right.$ at $\left.250^{\circ} \mathrm{C}\right)$ compared to that of $1 \mathrm{MZO}\left(>200 \mathrm{~s}\right.$ at $\left.250^{\circ} \mathrm{C}\right)$ sensor. The faster recovery time may be assigned to the larger surface area for chemical reaction provided by $\mathrm{Al}$ doping [46].

\subsubsection{Effect of Mg Doping on Al Doped ZnO NPs-Based Sensor for CO Sensing}

Carbon monoxide (CO) is an odorless, colorless, flammable and toxic gas which is produced by fossil fuel combustion, automotive emissions, industrial activities and household fuel-based devices. Exposure to high CO concentrations can provoke disorientation and 
loss of judgment and even death [47]. Figure 11 presents a histogram for the gas-sensing response of the $5 \mathrm{AZO}$ and $5 \mathrm{~A} 1 \mathrm{MZO}$ nanoparticles-based sensor towards $\mathrm{CO}$ gas. It is apparent that $5 \mathrm{AZO}$ displays high CO response. Indeed, many studies showed also the positive effect of aluminum doped $\mathrm{ZnO}$ on $\mathrm{CO}$ sensors [48-50]. The improved detection properties of $\mathrm{Al}$-doped $\mathrm{ZnO}$ samples is mainly attributed to electronic effects that alter the reactivity of the detection layer's surface [51]. In addition to this, it can be seen that the 5A1MZO response exhibits higher response compared to 5AZO-based sensor. Therefore, adding magnesium enhances the gas sensing properties of $5 \mathrm{AZO}$ sensor. According to work realized by Amin et al., the improvement of gas response may be related to the catalytic effect of magnesium, the provided defects such as oxygen vacancies, and also to the fast chemisorption and desorption of CO gas [52].

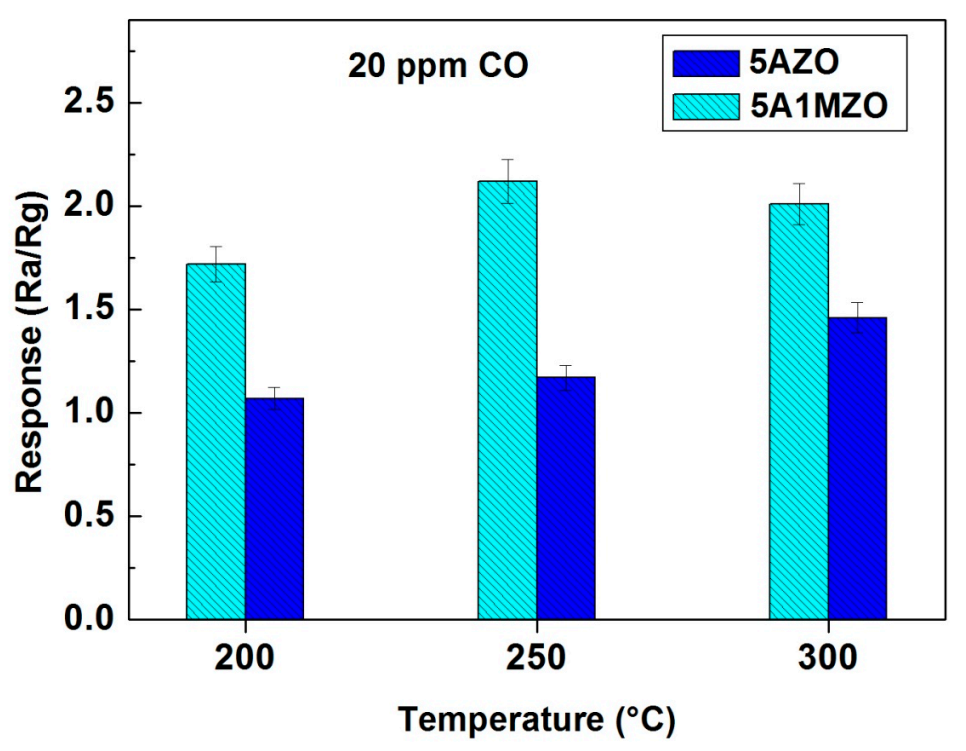

Figure 11. Responses of the $5 \mathrm{AZO}$ and $5 \mathrm{~A} 1 \mathrm{MZO}$ based sensors to $20 \mathrm{ppm} \mathrm{CO}$ versus operating temperatures.

\subsubsection{Gas Sensing Mechanism}

It is known that the gas sensing properties are considerably influenced by the carrier concentration and the chemisorbed oxygen species on the sensing materials surface. During the test process, the detected gas molecules are adsorbed and desorbed on the surface of the n-type semiconductor material and this causes the change of its resistance. When the sensor is exposed to air environment, plenty of oxygen molecules are adsorbed on the material surface. They capture free electrons from the $\mathrm{ZnO}$ conduction band and form different oxygen anions like $\mathrm{O}_{2}{ }^{-}, \mathrm{O}^{-}, \mathrm{O}^{2-}$ as well as a space charge depletion layer. Consequently, this process forms a depletion layer on the metal oxide nanomaterials surface and causes the increase of sensor resistance. The reactions process for the formation of different oxygen anions can be described as following (Equations (4)-(7)) [53].

$$
\begin{gathered}
O_{2(g a s)} \rightleftarrows O_{2(a d s)} \\
O_{2(a d s)}+e^{-} \rightleftarrows O_{2(a d s)}^{-} \\
O_{2(a d s)}^{-}+e^{-} \rightleftarrows 2 O_{(a d s)}^{-} \\
O_{(a d s)}^{-}+e^{-} \rightleftarrows O_{(a d s)}^{2-}
\end{gathered}
$$

After that, when a reducing gas such as $\mathrm{H}_{2}$ or $\mathrm{CO}$ is injected into the chamber, the gas molecules react with the oxygen anion and release the trapped electrons back to the $\mathrm{ZnO}$ conduction band. The space charge depletion layer on the $\mathrm{ZnO}$ surface is reduced and then 
the sensor resistance decreases. The interaction between the chemisorbed oxygen species and $\mathrm{H}_{2}$ and $\mathrm{CO}$ gas in the $200-300{ }^{\circ} \mathrm{C}$ range can be described as follows (Equations (8) and (9)):

$$
\begin{gathered}
\mathrm{H}_{2}+\mathrm{O}^{-}(\mathrm{ads}) \rightleftarrows \mathrm{H}_{2} \mathrm{O}+e^{-} \\
\mathrm{CO}+\mathrm{O}^{-} \rightarrow \mathrm{CO}_{2}+\bar{e}
\end{gathered}
$$

The effect of changing concentrations of tested gases $\left(\mathrm{H}_{2}, \mathrm{CO}\right)$ on the Al-Mg co-doped $\mathrm{ZnO}$-based sensor was analyzed. Figure 12a represents the concentration sensitivity curve of different $\mathrm{H}_{2}$ concentrations (100 to $30,000 \mathrm{ppm}$ ) at the operating temperature of $250{ }^{\circ} \mathrm{C}$. Figure 13a illustrates the sensitivity curves of different concentrations of $\mathrm{CO}(2-80 \mathrm{ppm})$ of $5 \mathrm{~A} 1 \mathrm{MZO}$-based sensor at $300^{\circ} \mathrm{C}$. It can be seen that the response of both testing gases increases whenever concentrations increase. Over the entire measured concentration range, the fabricated sensor presents a fully reversible response toward tested gas. Indeed, the sensor response decreases from $\mathrm{Ra}$ to $\mathrm{Rg}$ upon the injection of reducing gas and returns to its initial values ( $\mathrm{Ra}$ ) after ceasing the supply of the target gas. This behavior is attributed to the n-type semiconducting behavior of $\mathrm{ZnO}$ and to the reducing nature of the gases [54].
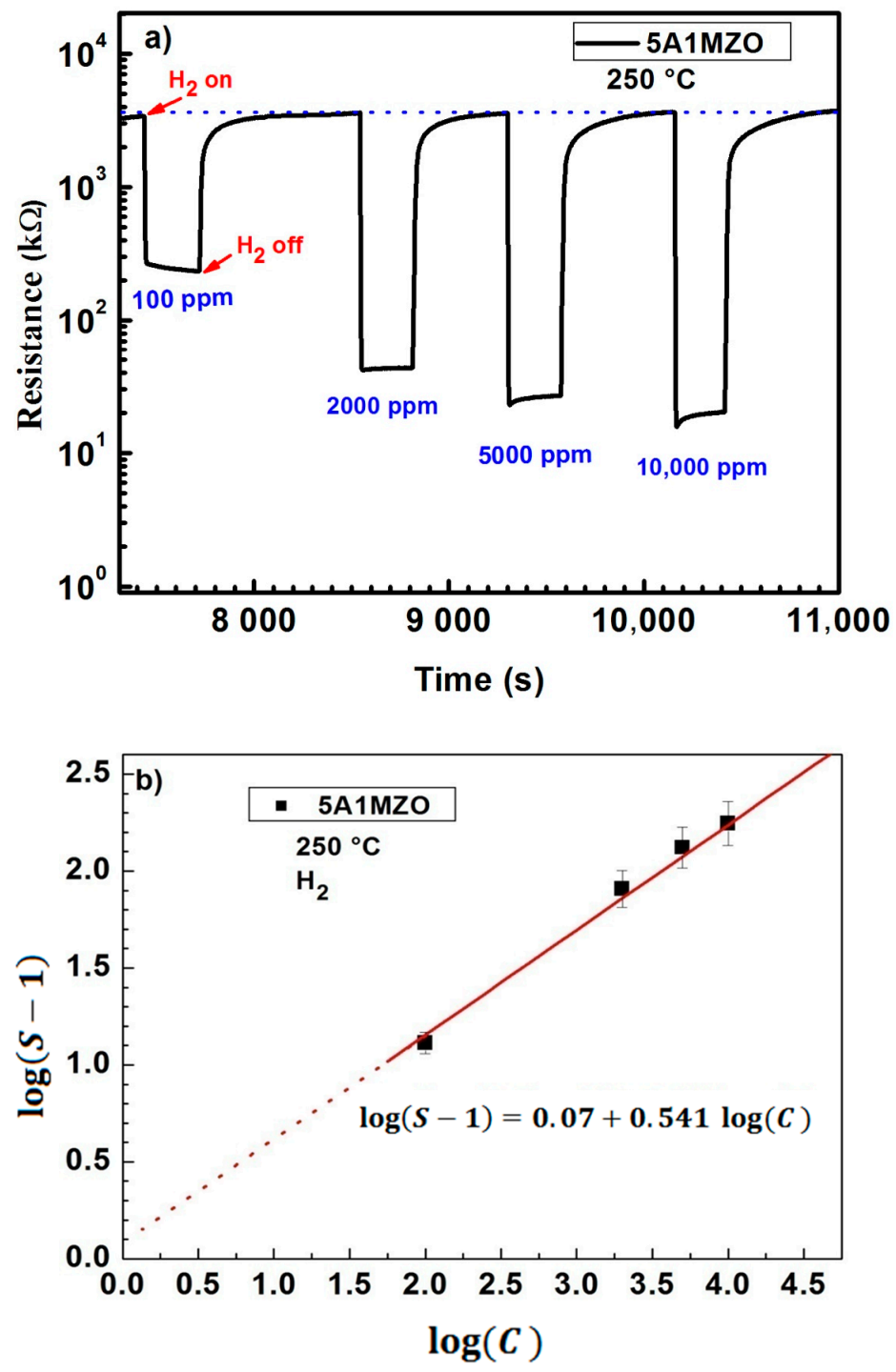

Figure 12. Cont. 


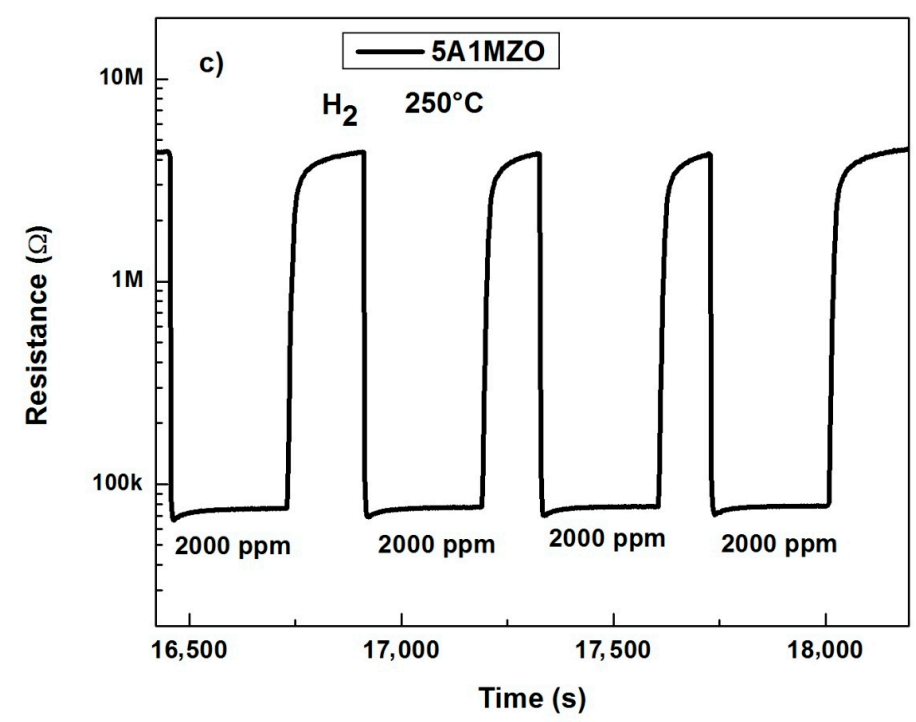

Figure 12. (a) Dynamic resistance change of $5 \mathrm{~A} 1 \mathrm{MZO}$ based sensor toward $\mathrm{H}_{2}$ gas, (b) its corresponding calibration curve, and (c) its reproducibility.
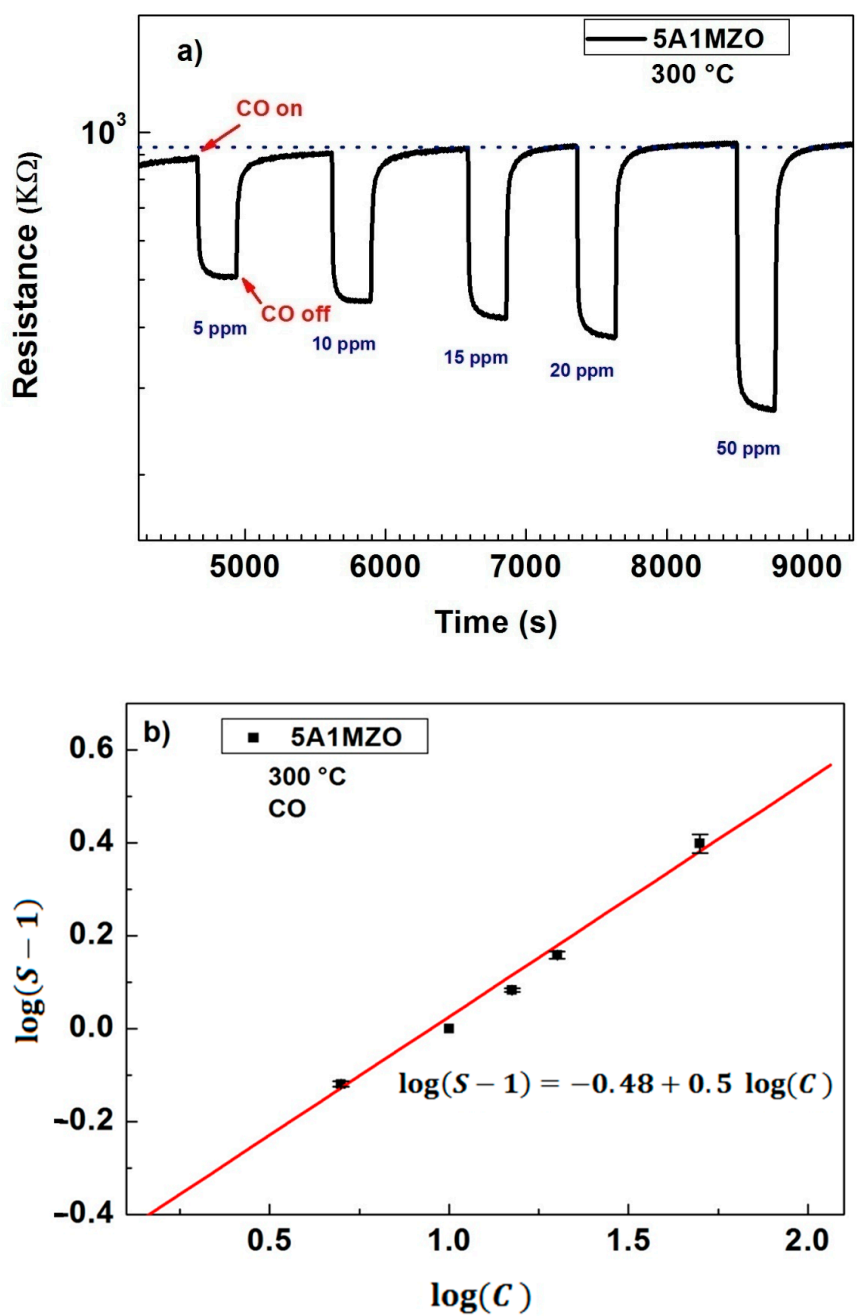

Figure 13. Cont. 


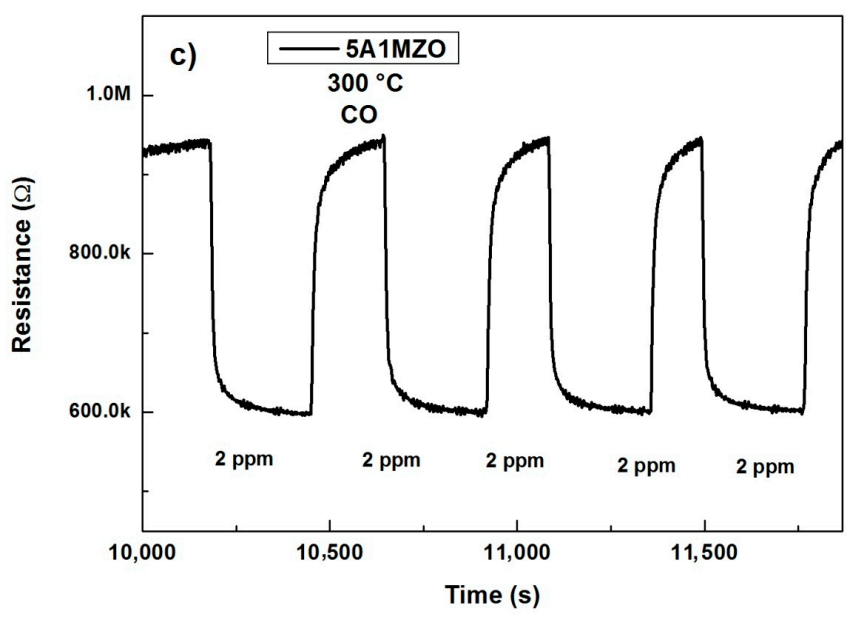

Figure 13. (a) Dynamic resistance change of $5 \mathrm{~A} 1 \mathrm{MZO}$ based sensor toward CO gas, (b) its corresponding calibration curve, and (c) its reproducibility.

The response of metal oxide semiconductor (MOS) gas sensors can be expressed according to the following relationship (Equation(10)) [44].

$$
\mathrm{S}=\mathrm{a}[\mathrm{C}]^{\mathrm{b}}+1
$$

where $\mathrm{S}$ is the gas response, $\mathrm{C}$ is the gas concentration, and $\mathrm{a}$ and $\mathrm{b}$ are constants. Generally, the ideal value of the exponent $\mathrm{b}$ is around 1 or 0.5 , depending on the charge state of the surface species, the stoichiometry of the elementary surface reactions between oxygen and tested gases, as well as microstructure of the materials [55]. Generally, it is 0.5 and 1 for the adsorbed oxygen ion $\mathrm{O}^{-}$and $\mathrm{O}^{2-}$, respectively. The $\mathrm{b}$ value can be calculated from the plot $\log (\mathrm{S}-1)$ versus $\log (\mathrm{C})$. Figures $12 \mathrm{~b}$ and $13 \mathrm{~b}$ show the $\log (\mathrm{S}-1)$ versus $\log (\mathrm{C})$ plot of 5A1MZO-based sensor toward different gases. As can be seen, there is a linear relationship of gas sensor response and gas concentration. The estimated $b$ values are 0.541 and 0.5 for $\mathrm{H}_{2}$, and $\mathrm{CO}$ gas, respectively; indicating that the oxygen ions absorbed on the surface are mainly $\mathrm{O}^{-}$. By extrapolating the linear graph, it can be noted a detection limit of few ppm of $\mathrm{H}_{2}(<2 \mathrm{ppm})$ and $\mathrm{CO}(<1 \mathrm{ppm})$.

Reproducibility was also studied, as mentioned in Figures 12c and 13c. The sensor showed good reproducibility towards 4 cycles of $2000 \mathrm{ppm} \mathrm{H}_{2}$ and $20 \mathrm{ppm} \mathrm{CO}$. Selectivity was also studied. Figure 14 shows the responses of the 5A1MZO sensor towards $2000 \mathrm{ppm}$ $\mathrm{H}_{2}, 20 \mathrm{ppm} \mathrm{CO}$ and $2000 \mathrm{ppm} \mathrm{CO}$ at temperature in the range of $200-300{ }^{\circ} \mathrm{C}$. The sensor showed high selectivity towards $\mathrm{H}_{2}$ gas at different temperatures.

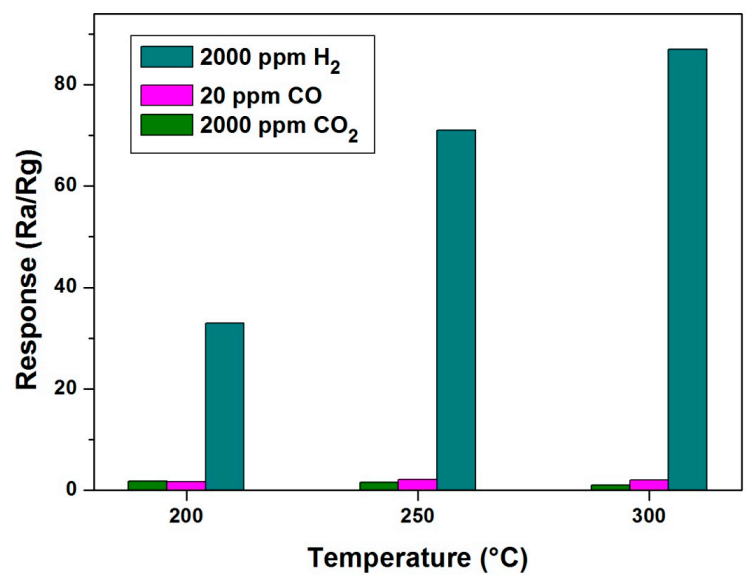

Figure 14. Selectivity of the 5A1MZO sensor when exposed to $2000 \mathrm{ppm} \mathrm{H}_{2}, 20 \mathrm{ppm} \mathrm{CO}$ and 2000 ppm $\mathrm{CO}_{2}$ at different temperatures $\left(200-300^{\circ} \mathrm{C}\right)$. 
Moreover, the performances of $5 \mathrm{~A} 1 \mathrm{MZO}$ sensor towards $\mathrm{H}_{2}$ and $\mathrm{CO}$ are summarized in Table 2 and compared with other resistance-type sensors. It can be seen from this table that $5 \mathrm{~A} 1 \mathrm{MZO}$ sensor have competitive results towards the reducing gases like $\mathrm{H}_{2}$ and $\mathrm{CO}$.

Table 2. Comparison of the results of current work with those recently reported on resistance type sensors for $\mathrm{H}_{2}$ and $\mathrm{CO}$.

\begin{tabular}{|c|c|c|c|c|c|c|c|}
\hline Gas & Sample & $\begin{array}{c}\text { Concentration } \\
(\mathrm{ppm})\end{array}$ & Response & $\begin{array}{c}\text { Temperature } \\
\left({ }^{\circ} \mathrm{C}\right)\end{array}$ & $\begin{array}{l}\text { Response } \\
\text { Time (s) }\end{array}$ & $\begin{array}{l}\text { Recovery } \\
\text { Time (s) }\end{array}$ & Reference \\
\hline \multirow{3}{*}{$\mathrm{H}_{2}$} & $\mathrm{WO}_{3} / \mathrm{TiO}_{2}$ nanofibers & 1000 & $(\mathrm{Rg}-\mathrm{Ra}) / \mathrm{Ra}=78.21 \%$ & RT & 20 & 23 & [56] \\
\hline & $\mathrm{Pd}-\mathrm{WO}_{3}$ composite thin films & 2000 & $\mathrm{Ra} / \mathrm{Rg}=2000$ & 250 & 7 & 299 & [57] \\
\hline & 5A1MZO NPs & 2000 & $\mathrm{Ra} / \mathrm{Rg}=70$ & 250 & 3 & 70 & This work \\
\hline \multirow{3}{*}{$\mathrm{CO}$} & In: $\mathrm{ZnO}$ thin films & 5 & $(\mathrm{Ra}-\mathrm{Rg}) / \mathrm{Rg}=4.17$ & 300 & 24 & 273 & [58] \\
\hline & Pt@ZnOpolyhedrons & 50 & $(\mathrm{Ra}-\mathrm{Rg}) / \mathrm{Ra}=65 \%$ & 125 & - & - & [47] \\
\hline & 5A1MZO NPs & 50 & $\mathrm{Ra} / \mathrm{Rg}=2.01$ & 300 & 24 & 35 & This work \\
\hline
\end{tabular}

\section{Conclusions}

$\mathrm{ZnO}, 1 \mathrm{MZO}, 5 \mathrm{AZO}$ and 5A1MZO NPs were synthesized by a modified sol-gel technique. XRD study showed the crystallized and hexagonal structure of prepared nanoparticles. TEM images of 5A1MZO and SEM images of $1 \mathrm{MZO}$ and 5A1MZO confirmed the nanometric sizes of the NPs. EDX results showed the purity of the 5A1MZO sample and confirmed the presence of $\mathrm{Al}$ and $\mathrm{Mg}$ in $\mathrm{ZnO}$ lattice. Absorbance spectra showed a strong absorption in the UV range. Optical band gaps were determined using Tauc's plot. The estimated value slightly increased with the addition of $\mathrm{Mg}$ loading and decreased with $\mathrm{Al}$ content. The effect of $\mathrm{Mg}$ and $\mathrm{Al}$ on improving the reducing gases $\mathrm{H}_{2}$ and $\mathrm{CO}$ was discussed. Sensing results indicated that the ternary $5 \mathrm{~A} 1 \mathrm{MZO}$-based sensor is sensitive to the reducing gases with low detection limit. It also showed good reproducibility towards $\mathrm{H}_{2}$ and $\mathrm{CO}$ and high selectivity towards $\mathrm{H}_{2}$ gas at different temperatures. Hence, the $5 \mathrm{~A} 1 \mathrm{MZO}$ sample is an inspiring sensing material for practical applications.

Author Contributions: Conceptualization, S.J., L.E.M., G.N.; Investigation, S.J., Y.A., I.A., I.G., C.B. H.D., G.N., L.E.M.; Writing-Original Draft Preparation, S.J.; Writing-Review \& Editing, L.E.M. All authors have read and agreed to the published version of the manuscript.

Funding: This work was funded by the National Plan for Sciences, Technology and innovation (MAARIFAH), King Abdulaziz City for Sciences and Technology, Kingdom of Saudi Arabia, award number: 13-NAN517-08.

Institutional Review Board Statement: Not applicable.

Informed Consent Statement: Not applicable.

Conflicts of Interest: The authors declare no conflict of interest.

\section{References}

1. Manjunath, G.; Nagaraju, P.; Mandal, S. Ultra-sensitive clogging free combustible molecular precursor-based screen-printed ZnO sensors: A detection of ammonia and formaldehyde breath markers. J. Mater. Sci. Mater. Electron. 2021, 32, 5713-5728. [CrossRef]

2. Rosli, N.; Halim, M.M.; Hashim, M.R. Effect of CBD growth times on the ZnO microrods prepared on macroporous silicon. Appl. Phys. A 2021, 127, 1-12. [CrossRef]

3. Que, M.; Lin, C.; Sun, J.; Chen, L.; Sun, X.; Sun, Y. Progress in ZnO Nanosensors. Sensors 2021, 21, 5502. [CrossRef]

4. Nakate, U.; Ahmad, R.; Patil, P.; Bhat, K.S.; Wang, Y.; Mahmoudi, T.; Yu, Y.; Suh, E.-K.; Hahn, Y.-B. High response and low concentration hydrogen gas sensing properties using hollow $\mathrm{ZnO}$ particles transformed from polystyrene@ZnO core-shell structures. Int. J. Hydrogen Energy 2019, 44, 15677-15688. [CrossRef]

5. Dhahri, R.; Leonardi, S.; Hjiri, M.; El Mir, L.; Bonavita, A.; Donato, N.; Iannazzo, D.; Neri, G. Enhanced performance of novel calcium/aluminum co-doped zinc oxide for $\mathrm{CO}_{2}$ sensors. Sens. Actuators B Chem. 2016, 239, 36-44. [CrossRef]

6. El Ghoul, J.; Omri, K.; El Mir, L.; Barthou, C.; Alaya, S. Sol-gel synthesis and luminescence properties of $\mathrm{SiO}_{2} / \mathrm{Zn}_{2} \mathrm{SiO}_{4}$ and $\mathrm{SiO}_{2} / \mathrm{Zn}_{2} \mathrm{SiO}_{4}: \mathrm{V}$ composite materials. J. Lumin. 2012, 132, 2288. [CrossRef]

7. Rajput, P.; Vashishtha, P.; Gupta, G.; Kamni. A comparative study on structural and optical properties of ZnO nanoparticles prepared by three different synthesis methods. Mater. Today Proc. 2021, 43, 3856-3861. [CrossRef] 
8. $\quad$ Nguyen, H.T.P.; Nguyen, T.M.T.; Hoang, C.N.; Le, T.K.; Lund, T.; Huynh, T.K.X. Characterization and photocatalytic activity of new photocatalysts based on Ag, F-modified $\mathrm{ZnO}$ nanoparticles prepared by thermal shock method. Arab. J. Chem. 2020, 13, 1837-1847. [CrossRef]

9. Anugrahwidya, R.; Yudasari, N.; Tahir, D. Optical and structural investigation of synthesis ZnO/Ag Nanoparticles prepared by laser ablation in liquid. Mater. Sci. Semicond. Process. 2019, 105, 104712. [CrossRef]

10. Taha, K.K.; Modwi, A.; Elamin, M.; Arasheed, R.; Al-Fahad, A.J.; Albutairi, I.; Arasheed, H.; Alfaify, M.; Anojaidi, K.; Algethami, F.K.; et al. Impact of Hibiscus extract on the structural and activity of sonochemically fabricated ZnO nanoparticles. J. Photochem. Photobiol. A Chem. 2019, 390, 112263. [CrossRef]

11. Husin, H.; Chen, H.-M.; Su, W.-N.; Pan, C.-J.; Chuang, W.-T.; Sheu, H.-S.; Hwang, B.-J. Green fabrication of La-doped NaTaO 3 via $\mathrm{H}_{2} \mathrm{O}_{2}$ assisted sol-gel route for photocatalytic hydrogen production. Appl. Catal. B Environ. 2010, 102, 343-351. [CrossRef]

12. Ali, S.; Gupta, A.; Shafiei, M.; Langford, S. Recent Advances in Perylene Diimide-Based Active Materials in Electrical Mode Gas Sensing. Chemosensors 2021, 9, 30. [CrossRef]

13. Singh, E.; Meyyappan, M.; Nalwa, H.S. Flexible graphene-based wearable gas and chemical sensors. ACS Appl. Mater. Interfaces 2017, 9, 34544-34586. [CrossRef]

14. Fazio, E.; Spadaro, S.; Corsaro, C.; Neri, G.; Leonardi, S.G.; Neri, F.; Lavanya, N.; Sekar, C.; Donato, N.; Neri, G. Metal-Oxide Based Nanomaterials: Synthesis, Characterization and Their Applications in Electrical and Electrochemical Sensors. Sensors 2021, 21, 2494. [CrossRef] [PubMed]

15. Wang, Y.; Meng, X.-N.; Cao, J.-l. Rapid detection of low concentration CO using Pt-loaded ZnO nanosheets. J. Hazard. Mater. 2020, 381, 120944. [CrossRef]

16. Ani, A.; Poornesh, P.; Nagaraja, K.; Kolesnikov, E.; Shchetinin, I.V.; Antony, A.; Kulkarni, S.D.; Sanjeev, G.; Petwal, V.C.; Verma, V.P. Tuning of $\mathrm{CO}$ gas sensing performance of spray pyrolyzed $\mathrm{ZnO}$ thin films by electron beam irradiation. Mater. Sci. Semicond. Process. 2020, 119, 105249. [CrossRef]

17. González-Garnica, M.; Galdámez-Martínez, A.; Malagón, F.; Ramos, C.; Santana, G.; Abolhassani, R.; Panda, P.K.; Kaushik, A.; Mishra, Y.K.; Karthik, T.V. One dimensional Au-ZnO hybrid nanostructures based $\mathrm{CO}_{2}$ detection: Growth mechanism and role of the seed layer on sensing performance. Sens. Actuators B Chem. 2021, 337, 129765. [CrossRef]

18. Nguyen, T.T.O.; Truong, T.H.; Le, A.T.; Dai Nguyen, T. Facile synthesis of different ZnO nanostructures for detecting sub-ppm $\mathrm{NO}_{2}$ gas. Mater. Today Commun. 2020, 22, 100826.

19. Lou, C.; Wang, K.; Mei, H.; Xie, J.; Zheng, W.; Liu, X.; Zhang, J. ZnO nanoarrays via a thermal decomposition-deposition method for sensitive and selective $\mathrm{NO}_{2}$ detection. Cryst. Eng. Comm. 2021, 23, 3654-3663. [CrossRef]

20. Kumar, M.; Bhati, V.S.; Ranwa, S.; Singh, J. Pd/ZnO nanorods based sensor for highly selective detection of extremely low concentration hydrogen. Sci. Rep. 2017, 7, 236. [CrossRef]

21. Yang, Y.; Wang, X.; Yi, G.; Li, H.; Shi, C.; Sun, G.; Zhang, Z. Hydrothermally synthesized porous ZnO nanosheets for methane sensing at lower temperature. J. Porous Mater. 2020, 27, 1363-1368. [CrossRef]

22. Kanaparthi, S.; Singh, S.G. Highly sensitive and ultra-fast responsive ammonia gas sensor based on 2D ZnO nanoflakes. Mater. Sci. Energy Technol. 2020, 3, 91-96. [CrossRef]

23. Nakarungsee, P.; Srirattanapibul, S.; Issro, C.; Tang, I.-M.; Thongmee, S. High performance Cr doped $\mathrm{ZnO}_{\text {by }} \mathrm{UV}_{\text {for }} \mathrm{NH}_{3}$ gas sensor. Sens. Actuators A Phys. 2020, 314, 112230. [CrossRef]

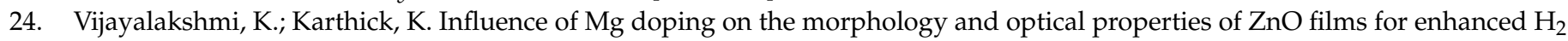
sensing. Microsc. Res. Tech. 2013, 76, 1118-1124. [CrossRef] [PubMed]

25. Agarwal, S.; Kumar, S.; Agrawal, H.; Moinuddin, M.G.; Kumar, M.; Sharma, S.K.; Awasthi, K. An Efficient Hydrogen Gas Sensor Based on Hierarchical Ag/ZnO Hollow Microstructures. Sens. Actuators B Chem. 2021, 130510. [CrossRef]

26. Jaballah, S.; Benamara, M.; Dahman, H.; Ly, A.; Lahem, D.; Debliquy, M.; Mir, L.E. Effect of Mg-doping ZnO nanoparticles on detection of low ethanol concentrations. Mater. Chem. Phys. 2020, 255, 123643. [CrossRef]

27. Jaballah, S.; Benamara, M.; Dahman, H.; Lahem, D.; Debliquy, M.; El Mir, L. Formaldehyde sensing characteristics of calciumdoped zinc oxide nanoparticles-based gas sensor. J. Mater. Sci. Mater. Electron. 2020, 31, 8230-8239. [CrossRef]

28. Samoei, V.K.; Jayatissa, A.H. Aluminum doped zinc oxide (AZO)-based pressure sensor. Sens. Actuators A Phys. 2020, $303,111816$. [CrossRef]

29. El Mir, L.; Ayadi, Z.B.; Saadoun, M.; Djessas, K.; von Bardeleben, H.J.; Alaya, S. Preparation and characterization of n-type conductive (Al, Co) co-doped $\mathrm{ZnO}$ thin films deposited by sputtering from aerogel nanopowders. Appl. Surf. Sci. 2007, 254, 570-573. [CrossRef]

30. Omri, K.; Alyamani, A.; El Mir, L. Photoluminescence and cathodoluminescence of Mn doped zinc silicate nanophosphors for green and yellow field emissions displays. Appl. Phys. A Mater. Sci. Process. 2018, 124, 215. [CrossRef]

31. Dhahri, R.; Hjiri, M.; Mir, L.E.; Bonavita, A.; Iannazzo, D.; Leonardi, S.G.; Neri, G. CO sensing properties under UV radiation of Ga-doped ZnO nanopowders. Appl. Surf. Sci. 2015, 355, 1321-1326. [CrossRef]

32. Muthukumaran, S.; Gopalakrishnan, R. Structural, FTIR and photoluminescence studies of Cu doped ZnO nanopowders by co-precipitation method. Opt. Mater. 2012, 34, 1946-1953. [CrossRef]

33. Karthik, S.; Siva, P.; Balu, K.S.; Suriyaprabha, R.; Rajendran, V.; Maaza, M. Acalypha indica-mediated green synthesis of ZnO nanostructures under differential thermal treatment: Effect on textile coating, hydrophobicity, UV resistance, and antibacterial activity. Adv. Powder Technol. 2017, 28, 3184-3194. [CrossRef] 
34. Han, B.; Liu, X.; Xing, X.; Chen, N.; Xiao, X.; Liu, S.; Wang, Y. A high response butanol gas sensor based on ZnO hollow spheres. Sens. Actuators B Chem. 2016, 237, 423-430. [CrossRef]

35. Boukhoubza, I.; Khenfouch, M.; Achehboune, M.; Leontie, L.; Galca, A.C.; Enculescu, M.; Carlescu, A.; Guerboub, M.; Mothudi, B.M.; Jorio, A. Graphene Oxide Concentration Effect on the Optoelectronic Properties of ZnO/GO Nanocomposites. Nanomaterials 2020, 10, 1532. [CrossRef] [PubMed]

36. Siregar, N.; Panggabean, J. The effect magnesium (Mg) on structural and optical properties of $\mathrm{ZnO}$ : Mg thin film by sol-gel spin coating method. J. Phys. Conf. Ser. 2020, 1428, 012026. [CrossRef]

37. Pradeev Raj, K.; Sadaiyandi, K.; Kennedy, A.; Sagadevan, S.; Chowdhury, Z.Z.; Johan, M.R.B.; Aziz, F.A.; Rafique, R.F.; Thamiz Selvi, R.; Rathina Bala, R. Influence of Mg Doping on ZnO Nanoparticles for Enhanced Photocatalytic Evaluation and Antibacterial Analysis. Nanoscale Res. Lett. 2018, 13, 229. [CrossRef] [PubMed]

38. Dhawan, R.; Panda, E. Mg addition in undoped and Al-doped ZnO films: Fabricating near UV transparent conductor by bandgap engineering. J. Alloy. Compd. 2019, 788, 1037-1047. [CrossRef]

39. Rouchdi, M.; Salmani, E.; Fares, B.; Hassanain, N.; Mzerd, A. Synthesis and characteristics of Mg doped ZnO thin films: Experimental and ab-initio study. Results Phys. 2017, 7, 620-627. [CrossRef]

40. Varudkar, H.; Umadevi, G.; Nagaraju, P.; Dargad, J.; Mote, V. Fabrication of Al-doped ZnO nanoparticles and their application as a semiconductor-based gas sensor for the detection of ammonia. J. Mater. Sci. Mater. Electron. 2020, 31, 12579-12585. [CrossRef]

41. Caglar, Y.; Caglar, M.; Ilican, S. Microstructural, optical and electrical studies on sol gel derived ZnO and ZnO: Al films. Curr. Appl. Phys. 2012, 12, 963-968. [CrossRef]

42. Hübert, T.; Boon-Brett, L.; Black, G.; Banach, U. Hydrogen sensors-A review. Sens. Actuators B Chem. 2011, 157, 329-352. [CrossRef]

43. Al-Asedy, H.J.; Bidin, N.; Al-khafaji, S.A.; Bakhtiar, H. Sol-gel grown aluminum/gallium co-doped ZnO nanostructures: Hydrogen gas sensing attributes. Mater. Sci. Semicond. Process. 2018, 77, 50-57. [CrossRef]

44. Khojier, K. Preparation and investigation of Al-doped $\mathrm{ZnO}$ thin films as a formaldehyde sensor with extremely low detection limit and considering the effect of RH. Mater. Sci. Semicond. Process. 2021, 121, 105283. [CrossRef]

45. Shi, Y.; Xu, H.; Liu, T.; Zeb, S.; Nie, Y.; Zhao, Y.; Qin, C.; Jiang, X. Advanced development of metal oxide nanomaterials for $\mathrm{H}_{2}$ gas sensing applications. Mater. Adv. 2021, 2, 1530-1569. [CrossRef]

46. Zhao, M.; Wang, X.; Cheng, J.; Zhang, L.; Jia, J.; Li, X. Synthesis and ethanol sensing properties of Al-doped ZnO nanofibers. Curr. Appl. Phys. 2013, 13, 403-407. [CrossRef]

47. Qin, C.; Wang, B.; Li, P.; Sun, L.; Han, C.; Wu, N.; Wang, Y. Metal-organic framework-derived highly dispersed Pt nanoparticlesfunctionalized $\mathrm{ZnO}$ polyhedrons for ppb-level CO detection. Sens. Actuators B Chem. 2021, 331, 129433. [CrossRef]

48. Zhang, J.; Yang, C.; Li, S.; Yang, P.; Xi, Y.; Cai, C.; Liu, W. Preparation of $\mathrm{Al}^{3+}$-doped ZnO micro-nanospheres for highly sensitive CO gas sensors. Appl. Phys. A 2021, 127, 176. [CrossRef]

49. Lim, S.K.; Hong, S.H.; Hwang, S.-H.; Choi, W.M.; Kim, S.; Park, H.; Jeong, M.G. Synthesis of Al-doped ZnO nanorods via microemulsion method and their application as a CO gas sensor. J. Mater. Sci. Technol. 2015, 31, 639-644. [CrossRef]

50. Hadipour, N.L.; Ahmadi Peyghan, A.; Soleymanabadi, H. Theoretical study on the Al-doped ZnO nanoclusters for CO chemical sensors. J. Phys. Chem. C 2015, 119, 6398-6404. [CrossRef]

51. Dhahri, R.; Hjiri, M.; El Mir, L.; Bonavita, A.; Iannazzo, D.; Latino, M.; Donato, N.; Leonardi, S.G.; Neri, G. Gas sensing properties of Al-doped ZnO for UV-activated CO detection. J. Phys. D Appl. Phys. 2016, 49, 135502. [CrossRef]

52. Amin, M.; Shah, N.A.; Bhatti, A.S.; Malik, M.A. Effects of Mg doping on optical and CO gas sensing properties of sensitive ZnO nanobelts. CrystEngComm 2014, 16, 6080-6088. [CrossRef]

53. Mohamed, R.; Mamat, M.; Ismail, A.; Malek, M.; Zoolfakar, A.; Khusaimi, Z.; Suriani, A.; Mohamed, A.; Ahmad, M.; Rusop, M. Hierarchically assembled tin-doped zinc oxide nanorods using low-temperature immersion route for low temperature ethanol sensing. J. Mater. Sci. Mater. Electron. 2017, 28, 16292-16305.

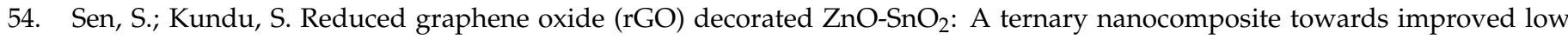
concentration VOC sensing performance. J. Alloys Compd. 2021, 881, 160406. [CrossRef]

55. Zhang, T.; Gu, F.; Han, D.; Wang, Z.; Guo, G. Synthesis, characterization and alcohol-sensing properties of rare earth doped $\mathrm{In}_{2} \mathrm{O}_{3}$ hollow spheres. Sens. Actuators B Chem. 2013, 177, 1180-1188. [CrossRef]

56. Kumaresan, M.; Venkatachalam, M.; Saroja, M.; Gowthaman, $\mathrm{P}^{\mathrm{TiO}_{2}}$ nanofibers decorated with monodispersed $\mathrm{WO}_{3}$ heterostruture sensors for high gas sensing performance towards $\mathrm{H}_{2}$ gas. Inorg. Chem. Commun. 2021, 129, 108663. [CrossRef]

57. Han, Z.; Ren, J.; Zhou, J.; Zhang, S.; Zhang, Z.; Yang, L.; Yin, C. Multilayer porous Pd-WO $\mathrm{WO}_{3}$ composite thin films prepared by sol-gel process for hydrogen sensing. Int. J. Hydrog. Energy 2020, 45, 7223-7233. [CrossRef]

58. Ani, A.; Poornesh, P.; Nagaraja, K.; Hegde, G.; Kolesnikov, E.; Shchetinin, I.V.; Antony, A.; Kulkarni, S.D. Evaluation of spray pyrolysed In: ZnO nanostructures for CO gas sensing at low concentration. J. Mater. Sci. Mater. Electron. 2021, 32, 22599-22616. [CrossRef] 